\title{
Candidate germline polymorphisms of genes belonging to the pathways of four drugs used in osteosarcoma standard chemotherapy associated with risk, survival and toxicity in non-metastatic high-grade osteosarcoma
}

\author{
Claudia M. Hattinger ${ }^{1}$, Paola Biason ${ }^{2}$, Erika Iacoboni ${ }^{1}$, Sara Gagno ${ }^{3}$, Marilù Fanelli' ${ }^{1}$ \\ Elisa Tavanti ${ }^{1}$, Serena Vella ${ }^{1}$, Stefano Ferrari ${ }^{4}$, Andrea Roli ${ }^{5}$, Rossana Roncato ${ }^{3}$, \\ Luciana Giodini ${ }^{3}$, Katia Scotlandi ${ }^{1}$, Piero Picci ${ }^{1}$, Giuseppe Toffoli ${ }^{3}$, Massimo Serra ${ }^{1}$ \\ ${ }^{1}$ Laboratory of Experimental Oncology, Orthopaedic Rizzoli Institute, Bologna, Italy \\ ${ }^{2}$ National Institute of Health and Medical Research (INSERM), Unity 892, University of Medicine of Angers, Angers, France \\ ${ }^{3}$ Experimental and Clinical Pharmacology Unit, National Cancer Institute, Aviano, Italy \\ ${ }^{4}$ Chemotherapy Ward of Muscoloskeletal Tumours, Orthopaedic Rizzoli Institute, Bologna, Italy \\ ${ }^{5}$ Department of Computer Science and Engineering (DISI), University of Bologna, Cesena, Italy
}

Correspondence to: Massimo Serra, email: massimo.serra@ior.it

Keywords: osteosarcoma, germline polymorphisms, toxicity, drug response biomarkers, personalized medicine

Received: June 01, $2016 \quad$ Accepted: July 29, $2016 \quad$ Published: August 22, 2016

\section{ABSTRACT}

This study aimed to identify associations between germline polymorphisms and risk of high-grade osteosarcoma (HGOS) development, event-free survival (EFS) and toxicity in HGOS patients treated with neo-adjuvant chemotherapy and surgery.

Germline polymorphisms of $\mathbf{3 1}$ genes known to be relevant for transport or metabolism of all four drugs used in HGOS chemotherapy (methotrexate, doxorubicin, cisplatin and ifosfamide) were genotyped in 196 patients with HGOS and in 470 healthy age and gender-matched controls. Of these 196 HGOS patients, a homogeneously treated group of 126 patients was considered for survival analyses (survival cohort). For $\mathbf{5 7}$ of these, treatment-related toxicity data were available (toxicity cohort).

Eleven polymorphisms were associated with increased risk of developing HGOS $(p<0.05)$. The distribution of polymorphisms in patients was characterized by a higher Shannon entropy. In the survival cohort $(n=126$, median follow-up $=126$ months), genotypes of ABCC2_1249A/G, GGH_452T/C, TP53_IVS2+38G/C and CYP2B6* 6 were associated with EFS $(p<0.05)$. In the toxicity cohort $(n=57)$, genotypes of ABCB1_1236T/C, ABCC2_1249A/G, ABCC2_3972A/G, ERCC1_8092T/G, XPD_23591A/G, XRCC3_18067T/C, MTHFR_1298A/C and GGH_16T/C were associated with elevated risk for toxicity development $(p<0.05)$.

The results obtained in this retrospective study indicate that the aforementioned germline polymorphisms significantly impact on the risk of HGOS development, EFS and the occurrence of chemotherapy-related toxicity. These findings should be prospectively validated with the aim of optimizing and tailoring HGOS treatment in the near future.

\section{INTRODUCTION}

High-grade osteosarcoma (HGOS) is the most common malignant bone tumor arising in children and young adults. Current treatment of non-metastatic HGOS consists of surgical removal of the primary tumor and systemic pre- and post-operative multidrug chemotherapy. Standard protocols include doxorubicin, cisplatin, high-dose methotrexate and/or ifosfamide and/or etoposide, which allow to cure about $60-65 \%$ of patients with conventional HGOS (non-metatstatic at diagnosis, tumor localized in the extremities in patients younger than 40 years) [1-3]. 
Pharmacogenomic information regarding the drugs used in HGOS standard chemotherapy were obtained in other more frequent malignancies, and potentially common pathways and functional polymorphisms in these proteins that influence both chemotherapy toxicity and outcome were identified (https://www.pharmgkb.org/). On the other hand, a number of case-control studies revealed a series of polymorphisms associated with increased risk for HGOS development (https://phgkb.cdc.gov/ HuGENavigator/startPagePhenoPedia.do, [4]) but none of these was confirmed by a recent international genomewide-association-study approach [5].

The primary aim of this study was the identification of germline polymorphisms associated with HGOS development and comparison of their distribution in the cohort of controls $(n=470)$ with the one in the cohort of HGOS patients $(n=196)$ by means of informationtheoretical measures. The secondary aim was the identification of polymorphisms with an impact on event-free survival (EFS) in a subgroup of 126 patients with conventional HGOS treated with neo-adjuvant chemotherapy, including methotrexate, doxorubicin, cisplatin and ifosfamide, and surgical removal of the primary tumor. The third aim consisted in the investigation of associations between genotypes and treatment-related toxicity in a subgroup of 57 patients with registered toxic events.

\section{RESULTS}

To assess the effect of the different alleles of each polymorphism, data were classified as follows: "Wild-type" (WT) as homozygous status of the most frequent allele as reported in the reference public database (Table 1), "Hetero" (HET) as the heterozygous status of the variant allele and "Variant" (VAR) as the homozygous status of the variant allele.

In order to enable $2 \times 2$ table and logistic regression analyses genotypic data were also categorized in two groups according to 1) the dominant model: WT versus HET + VAR and 2) the recessive model: WT + HET versus VAR. For three polymorphisms without public frequency data, WT was classified as follows: DHFR Ins/Del (rs70991108) and TYMS_1494del6 (rs16430) homozygous without deletion; TP53_PIN_IVS3+16bp (rs17878362) homozygous without insertion.

\section{Genotypes associated with risk for osteosarcoma development}

Frequencies of the WT, HET and VAR status of all polymorphisms were calculated for the healthy controls $(n=470)$ and the total cohort of patients with HGOS $(n=196)$ (Table 2). Genotype frequencies of controls were similar to those reported in public databases demonstrating its representativeness.
Contingency analyses identified 12 polymorphisms that were significantly differently distributed in HGOS patients relative to healthy controls (Table 2). In order to obtain larger group sizes and thus more robust results, patients were grouped according to either the dominant or recessive genotypic model. These analyses identified one additional polymorphism MTHFR_677T/C (VAR versus WT $+\mathrm{HET}, p=0.021)$ that was significantly differently distributed in HGOS patients compared to healthy controls.

Shannon entropy was computed for all the polymorphisms and all the three genotypic models (Figure 1). The difference between the two cohorts was remarkable: the entropy in patients was higher than the one in controls in $52 \%$ of the cases, while it was lower in $45 \%$ of the cases. In the remaining 3\% the entropy values were equal. Besides the simple counting of cases with higher/lower entropy, it is important to observe that the cases with higher patient entropy seem to be characterized by a larger difference of entropy values. To assess this hypothesis, we applied a Wilcoxon test with a 95\% confidence level. The resulting $p$ value of 0.021 provided significant evidence that the entropy of the polymorphism distribution in patients was higher than in controls. The most notable differences with $r$, which is the ratio between patients and controls entropy of a given polymorphism distribution, greater than 1.5 were found for the following polymorphisms in the recessive model: ABCC2_3972A/G, ABCG2_421A/C, ATM_61A/G, TP53_IVS $2+38 \mathrm{G} / \mathrm{C}$, CYP2B 6*6, GGH_452T/C, TP53_IVS2+38G/C, CYP2C9*3_1075A/C, GGH_452T/C, GGH_401T/C, GGH_16T/C, hOGG1_1245C/G and XPG_3508G/C.

Cluster index analysis was applied and revealed that the average values of $\mathrm{Tc}$ (which is a clustering significance measure and was computed as described in detail in the supplementary information) were much higher in controls then in patients. In general, the highest Tc values in controls were about three times the Tc values of patients. This outcome provided further evidence supporting the fact that the distribution of polymorphisms in patients was more heterogeneous than in controls.

To determine whether the differently distributed polymorphisms were associated also with an increased risk for HGOS development, simple logistic regression analysis was performed on the data according to the dominant or recessive genotypic model. Eleven polymorphisms resulted to be associated with increased risk for HGOS development (Table 3).

\section{Genotypes with impact on event-free survival in osteosarcoma patients}

To identify genotypes with impact on clinical outcome, survival analyses were performed for each polymorphism in a subgroup of $126 \mathrm{HGOS}$ patients with homogeneous clinico-pathological features and treatment 
Table 1: Characteristics of germline polymorphisms included in the study

\begin{tabular}{|c|c|c|c|c|c|c|c|}
\hline $\begin{array}{l}\text { Main gene } \\
\text { function }\end{array}$ & $\begin{array}{l}\text { Gene Name__ } \\
\text { Polymorphism }\end{array}$ & $\begin{array}{c}\text { Reference } \\
\text { SNP } \\
\text { number }\end{array}$ & $\begin{array}{l}\text { Type of } \\
\text { change }\end{array}$ & Function & $\begin{array}{l}\text { Effect on } \\
\text { protein }\end{array}$ & $\begin{array}{c}\text { Most } \\
\text { frequent } \\
\text { allele in } \\
\text { database }\end{array}$ & $\begin{array}{l}\text { Pubblic database } \\
\text { used as reference }\end{array}$ \\
\hline \multirow{9}{*}{ 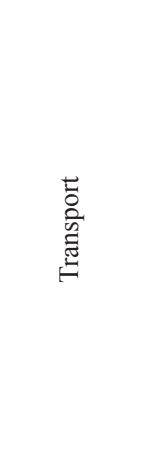 } & ABCB1_3435T/C & rs 1045642 & SNV & cds-synon & Ile1145Ile & $\mathrm{T}$ & HAPMAPCEU \\
\hline & ABCB1_1236T/C & rs1128503 & SNV & cds-synon & Gly412Gly & $\mathrm{C}$ & HAPMAPCEU \\
\hline & ABCB1_2677G > T/A & rs2032582 & SNV & missense & Ser893Thr & G & HAPMAPCEU \\
\hline & ABCC2_1249A/G & rs2273697 & SNV & missense & Val417Ile & G & HAPMAPCEU \\
\hline & $\mathrm{ABCC} 2 \_-24 \mathrm{~A} / \mathrm{G}$ & rs 717620 & SNV & UTR-5 & NA & G & HAPMAPCEU \\
\hline & ABCC2_3972A/G & rs3740066 & SNV & cds-synon & Ile1092Ile & G & HAPMAPCEU \\
\hline & ABCG2_34A/G & rs2231137 & SNV & missense & Val12Met & G & HAPMAPCEU \\
\hline & ABCG2_421A/C & rs 2231142 & SNV & missense & Gln141Lys & $\mathrm{C}$ & HAPMAPCEU \\
\hline & RFC_80A/G & rs1051266 & SNV & missense & His27Arg & G & HAPMAPCEU \\
\hline \multirow{11}{*}{  } & APE1_2197T/G & rs1130409 & SNV & missense & Asp148Glu & G & HAPMAPCEU \\
\hline & ERCC1_8092T/G & rs3212986 & SNV & UTR-3 & NA & G & HAPMAPCEU \\
\hline & ERCC1_19007T/C & rs11615 & SNV & cds-synon & Asn118Asn & $\mathrm{T}$ & HAPMAPCEU \\
\hline & hMLH1_676A/G & rs1799977 & SNV & missense & Ile219Ile & A & HAPMAPCEU \\
\hline & hMSH2_IVS12-6T/C & rs2303428 & SNV & $\begin{array}{c}\text { splice region and intron } \\
\text { variant }\end{array}$ & NA & $\mathrm{T}$ & HAPMAPCEU \\
\hline & hOGG1_1245C/G & rs 1052133 & SNV & missense & Ser326Cys & $\mathrm{C}$ & HAPMAPCEU \\
\hline & XPD_35931T/G & rs 13181 & SNV & missense & Lys727Gln & $\mathrm{T}$ & HAPMAPCEU \\
\hline & XPD_23591A/G & rs1799793 & SNV & missense & Asp288Asn & G & HAPMAPCEU \\
\hline & XPG_3508G/C & $\mathrm{rs} 17655^{\mathrm{HW}}$ & SNV & missense & Asp1104His & $\mathrm{C}$ & HAPMAPCEU \\
\hline & XRCC1_28152A/G & rs 25487 & SNV & missense & Gln399Arg & G & HAPMAPCEU \\
\hline & XRCC3_18067T/C & rs861539 & SNV & missense & Thr241Met & $\mathrm{C}$ & HAPMAPCEU \\
\hline \multirow{11}{*}{$\begin{array}{l}\frac{0}{0} \\
0 \\
0 \\
0 \\
\frac{\pi}{0} \\
0\end{array}$} & DHFR_Ins/Del & rs70991108 & DIV & nearGene-5/1st intron & NA & Ins & [6] \\
\hline & FOLR1_181delC & rs3833748 & DIV & nearGene-5 & NA & I & CAUC1 \\
\hline & GGH_452T/C & rs11545078 & SNV & missense & Thr151Ile & $\mathrm{C}$ & HAPMAPCEU \\
\hline & GGH_401T/C & rs $3758149^{\mathrm{HW}}$ & SNV & nearGene-5 & NA & $\mathrm{C}$ & HAPMAPCEU \\
\hline & GGH_16T/C & rs $1800909^{\mathrm{HW}}$ & SNV & missense & Cys6Arg & $\mathrm{T}$ & PILOT1 \\
\hline & MTHFD1_1958T/C & rs 2236225 & SNV & missense & Arg653Gln & $\mathrm{C}$ & HAPMAPCEU \\
\hline & MTHFR_677T/C & rs 1801133 & SNV & missense & Ala222Val & $\mathrm{C}$ & HAPMAPCEU \\
\hline & MTHFR_1298A/C & rs 1801131 & SNV & missense & Glu429Ala & A & HAPMAPCEU \\
\hline & SHMT_1420T/C & rs2273029 & SNV & intron variant & NA & $\mathrm{C}$ & HAPMAPCEU \\
\hline & TYMS_28bp_VNTR & rs34743033 & STR & NA & NA & 3 (repeats) & CAUC1 \\
\hline & TYMS_1494del6 & rs 16430 & DIV & $\begin{array}{l}6 \text { bp deletion in micro- } \\
\text { RNA binding site }\end{array}$ & NA & NA & $\begin{array}{l}\text { excluded from } \\
\text { SNPdb }\end{array}$ \\
\hline \multirow{7}{*}{$\begin{array}{l}\frac{n}{2} \\
0 \\
0 \\
0 \\
0 \\
\frac{2}{4}\end{array}$} & ATM_40C/G & rs 1800054 & SNV & missense & Ser49Cys & $\mathrm{C}$ & CAUC1 \\
\hline & ATM_61A/G & rs 1801516 & SNV & missense & Asp1853Asn & G & HAPMAPCEU \\
\hline & MDM2_309T/G & rs2279744 & SNV & intron variant & NA & $\mathrm{T}$ & PILOT1 \\
\hline & p21_98A/C & rs 1801270 & SNV & missense & Ser31Arg & $\mathrm{C}$ & HAPMAPCEU \\
\hline & TP53_PIN3_IVS3 + 16 bp & rs17878362 & STR & NA & NA & NA & $\begin{array}{c}\text { no frequence data } \\
\text { available }\end{array}$ \\
\hline & TP53_IVS2+38G/C & rs1642785 & SNV & UTR-5 & NA & G & PILOT1 \\
\hline & TP53_ex4+119G/C & $\mathrm{rs} 1042522^{\mathrm{HW}}$ & SNV & missense & Pro72Arg & G & HAPMAPCEU \\
\hline
\end{tabular}




\begin{tabular}{|c|c|c|c|c|c|c|c|}
\hline \multirow{9}{*}{ 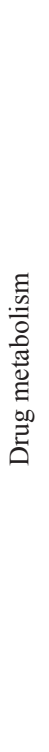 } & GSTT1_gen_null & $\begin{array}{c}\text { rs_GSTT1_ } \\
\text { gen_null }\end{array}$ & DIV & $\begin{array}{l}\text { reduced or no protein } \\
\text { activity }\end{array}$ & NA & null & [7] \\
\hline & GSTM1_gen_null & $\begin{array}{l}\text { rs_GSTM1__ } \\
\text { gen_null }\end{array}$ & DIV & $\begin{array}{l}\text { reduced or no protein } \\
\text { activity }\end{array}$ & NA & non-null & [7] \\
\hline & GSTP1_313A/G & rs 1695 & SNV & missense & Ile105Val & A & HAPMAPCEU \\
\hline & CYP2C19*2_681A/G & rs 4244285 & SNV & cds-synon & Pro227Pro & G & HAPMAPCEU \\
\hline & $\begin{array}{l}\text { CYP2B6*6 } \\
(516 \mathrm{~T} / \mathrm{G}+785 \mathrm{~A} / \mathrm{G})\end{array}$ & $\begin{array}{c}\text { rs } 3745274 \\
\text { and } \\
\text { rs } 2279343\end{array}$ & Haplotype & $\begin{array}{l}\text { reduced protein } \\
\text { expression }\end{array}$ & $\begin{array}{l}\text { Gln172His; } \\
\text { Lys262Arg }\end{array}$ & NA & [8] \\
\hline & $\begin{array}{l}\text { CYP2B6*7 } \\
(* 6+1459 \mathrm{~T} / \mathrm{C})\end{array}$ & $\begin{array}{l}\text { rs } 3745274 \\
\text { and } \\
\text { rs } 2279343 \\
\text { and } \\
\text { rs } 3211371\end{array}$ & Haplotype & $\begin{array}{l}\text { reduced protein } \\
\text { expression }\end{array}$ & $\begin{array}{l}\text { Gln172His; } \\
\text { Lys262Arg; } \\
\text { Arg487Cys }\end{array}$ & NA & [8] \\
\hline & CYP2C9*2_430T/C & rs 1799853 & SNV & missense & Arg144Cys & $\mathrm{C}$ & HAPMAPCEU \\
\hline & CYP2C9*3_1075A/C & rs 1057910 & SNV & missense & Ile359Leu & A & HAPMAPCEU \\
\hline & CYP3A4*1B_-392A/G & rs2740574 & SNV & nearGene-5 & NA & A & EGP_CEPH-PANEL \\
\hline
\end{tabular}

HW: polymorphism with significant deviation from Hardy-Weinberg equilibrium $(P<0.01)$; SNV: single nucleotide variation, DIV: deletion/insertion variation, STR: short tandem repeat (microsatellite) variation, cds-synon: coding region - synonymous, UTR: untranslated region, NA: not applicable.

(Table 4). This subgroup was representative of the whole patient series since frequency distributions of all genotypes and clinico-pathological parameters were similar to those of all the 196 patients (Tables 2 and 5).

Four polymorphisms, ABCC2_1249A/G, GGH_452T/C, TP53IVS2 + 38C $>\mathrm{G}$ and CYP2B6*6, were significantly associated with EFS in univariate analysis (Figure 2). Worse EFS was associated with the genotypes HET + VAR of ABCC2_1249A/G (A), VAR of GGH $\_452 \mathrm{~T} / \mathrm{C}$ (B), WT + HET of TP53IVS2 + 38C $>$ G (C) and VAR of CYP2B6*6 (D). However none of these genotypes, which we defined as "risk genotypes", retained statistical significance by multiparametric Cox proportional hazards regression analysis (data not shown). By using the true median EFS times as input data, all four polymorphisms reached a power of at least $55 \%$ (range $46-100 \%$ ) (type I error 5\%) to detect survival differences between the two groups characterized by the different genotypes.

Based on the evidence that the aforementioned risk genotypes individually impacted on EFS, we stratified patients into four risk groups. Nine patients were excluded because they did not have data of all these four polymorphisms. As shown in Figure 3, patients carrying three or four risk genotypes $(n=4)$ performed significantly worse, compared to patients with two $(n=32)$, one $(n=40)$ or none $(n=41)$ risk genotypes (A). This difference was even more evident when patients with one or two risk genotypes were grouped together (B).

None of the genotypes resulted in a statistically significant association with any of the clinical parameters shown in Table 4, which did also not impact on survival (data not shown).

\section{Toxicity associated with genotypes in osteosarcoma patients}

Possible associations between chemotherapy-related toxicity and polymorphisms were evaluated in a subgroup of 57 patients enroled in the ISG/OS-1 protocol. For these analyses, genotype data were categorized according to the dominant model in WT and HET + VAR, in order to avoid too small sample sizes.

Eight polymorphisms proved to be significantly associated with toxic events (Table 6). Significant predictivity was confirmed for five of them by multiple logistic regression analysis (Table 6). Neurotoxicity was registered in four patients $(7 \%)$, but no predictive polymorphism was identified. Nephrotoxicity and stomatitis were registered in one patient each $(2 \%)$ and were therefore not included in association analyses.

Because of the different toxicity profile of methotrexate compared to doxorubicin, cisplatin and ifosfamide, logistic regression analyses were performed to estimate the relative risk for the occurrence of toxic events in relation to the drugs administered (Table 7). Considering methotrexate cycles, WT status of ABCC2_3972A/G was associated with nausea and vomiting, as well as ABCB1 1236T/C (HET + VAR), ABCC2 1249 (WT) and GGH_16T/C (WT) with transaminases increase grade 4 . All three polymorphisms remained significant for transaminases increase grade 4 by multiple regression analysis (Table 7).

Regarding doxorubicin, cisplatin and ifosfamide cycles, a higher risk for leukopenia was associated with the presence of at least one variant allele of ABCC2_1249A/G and MTHFR_1298A/C. ABCC2_1249A/G (HET + VAR) 
Table 2: Genotype frequencies in 196 osteosarcoma patients and 470 healthy controls

\begin{tabular}{|c|c|c|c|c|c|c|c|c|}
\hline \multirow[b]{2}{*}{$\begin{array}{l}\text { Main Gene } \\
\text { Function }\end{array}$} & \multirow[b]{2}{*}{ Polymorphism } & \multicolumn{3}{|c|}{196 Patients } & \multicolumn{3}{|c|}{470 Healthy controls } & \multirow[b]{2}{*}{$p$} \\
\hline & & WT (\%) & HET (\%) & VAR (\%) & WT (\%) & HET (\%) & VAR (\%) & \\
\hline \multirow{9}{*}{ 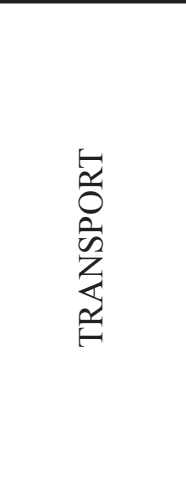 } & ABCB1_3435T/C & 26 & 44 & 30 & 24 & 52 & 24 & \multirow{9}{*}{0.011} \\
\hline & ABCB1_1236T/C & 32 & 45 & 23 & 33 & 50 & 17 & \\
\hline & ABCB1_2677G/T/A & 29 & 48 & 23 & 28 & 53 & 19 & \\
\hline & ABCC2_1249A/G & 50 & 46 & 4 & 63 & 34 & 3 & \\
\hline & $\mathrm{ABCC} 2 \_-24 \mathrm{~A} / \mathrm{G}$ & 60 & 37 & 3 & 66 & 30 & 4 & \\
\hline & ABCC2_3972A/G & 46 & 36 & 18 & 47 & 44 & 9 & \\
\hline & ABCG2_34A/G & 84 & 16 & 0 & 88 & 11 & 1 & \\
\hline & $\mathrm{ABCG} 2 \_421 \mathrm{~A} / \mathrm{C}$ & 85 & 13 & 2 & 80 & 19 & 1 & \\
\hline & $\mathrm{RFC} \_80 \mathrm{~A} / \mathrm{G}$ & 39 & 45 & 16 & 37 & 49 & 14 & \\
\hline \multirow{11}{*}{ 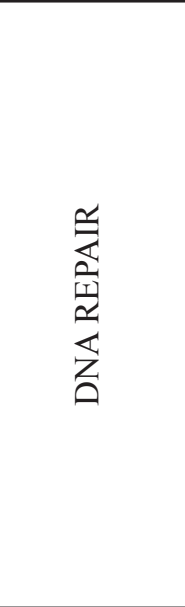 } & APE1_2197T/G & 16 & 50 & 34 & 20 & 49 & 31 & \multirow{11}{*}{0.010} \\
\hline & ERCC1_8092T/G & 62 & 32 & 6 & 54 & 39 & 7 & \\
\hline & ERCC1_19007T/C & 34 & 43 & 23 & 35 & 47 & 18 & \\
\hline & hMLH1_676A/G & 33 & 54 & 13 & 45 & 41 & 14 & \\
\hline & hMSH2_IVS12-6T/C & 85 & 14 & 1 & 86 & 13 & 1 & \\
\hline & hOGG1_1245C/G & 65 & 29 & 6 & 63 & 33 & 4 & \\
\hline & XPD_35931T/G & 40 & 45 & 15 & 38 & 46 & 16 & \\
\hline & XPD_23591A/G & 43 & 40 & 17 & 44 & 41 & 15 & \\
\hline & XPG_3508G/C & 57 & 31 & 12 & 54 & 41 & 5 & \\
\hline & XRCC1_28152A/G & 42 & 44 & 14 & 44 & 45 & 11 & \\
\hline & XRCC3_18067T/C & 32 & 51 & 17 & 38 & 44 & 18 & \\
\hline \multirow{11}{*}{ 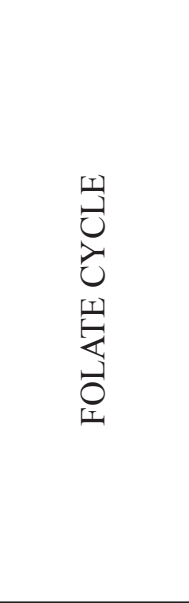 } & DHFR_Ins/Del & 34 & 50 & 16 & 35 & 55 & 10 & \multirow{11}{*}{$\begin{array}{l}0.042 \\
0.011\end{array}$} \\
\hline & FOLR1_181delC & 96 & 4 & 0 & 97 & 3 & 0 & \\
\hline & GGH_452T/C & 82 & 15 & 3 & 79 & 20 & 1 & \\
\hline & GGH_401T/C & 53 & 31 & 16 & 52 & 40 & 8 & \\
\hline & GGH_16T/C & 63 & 22 & 15 & 57 & 35 & 8 & \\
\hline & MTHFD1_1958T/C & 27 & 53 & 20 & 28 & 50 & 22 & \\
\hline & MTHFR_677T/C & 30 & 49 & 21 & 32 & 55 & 13 & \\
\hline & MTHFR_1298A/C & 47 & 44 & 9 & 41 & 47 & 12 & \\
\hline & SHMT_1420T/C & 52 & 38 & 10 & 58 & 34 & 8 & \\
\hline & TYMS_28bp_VNTR & 44 & 39 & 17 & 32 & 45 & 23 & \\
\hline & TYMS_1494del6 & 30 & 54 & 16 & 37 & 47 & 16 & \\
\hline \multirow{7}{*}{$\begin{array}{l}\tilde{N} \\
\tilde{n} \\
0 \\
\qquad \\
0 \\
0 \\
\&\end{array}$} & ATM_40C/G & 98 & 2 & 0 & 96 & 4 & 0 & \multirow{5}{*}{$<0.001$} \\
\hline & ATM_61A/G & 72 & 25 & 3 & 77 & 22 & 1 & \\
\hline & MDM2_309T/G & 34 & 42 & 24 & 47 & 41 & 12 & \\
\hline & p21_98A/C & 84 & 15 & 1 & 85 & 14 & 1 & \\
\hline & $\begin{array}{l}\text { TP53_PIN3_- } \\
\text { IVS3+16bp }\end{array}$ & 68 & 25 & 7 & 69 & 27 & 4 & \\
\hline & TP53_IVS2+38G/C & 8 & 33 & 59 & 56 & 36 & 8 & $<0.0001$ \\
\hline & TP53_ex4+119G/C & 71 & 21 & 8 & 59 & 34 & 7 & 0.007 \\
\hline
\end{tabular}




\begin{tabular}{|c|c|c|c|c|c|c|c|c|}
\hline \multirow{9}{*}{ 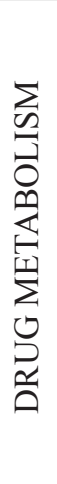 } & GSTT1_gen_null & 84 & 0 & 16 & 81 & 0 & 19 & \\
\hline & GSTM1_gen_null & 43 & 0 & 57 & 47 & 0 & 53 & \\
\hline & GSTP1_313A/G & 48 & 44 & 8 & 51 & 43 & 6 & \\
\hline & CYP2C19*2_681A/G & 74 & 23 & 3 & 73 & 25 & 2 & \\
\hline & CYP2B6*6 & 66 & 27 & 7 & 58 & 38 & 4 & 0.030 \\
\hline & CYP2B6*7 & 99 & 1 & $\mathbf{0}$ & 96 & 4 & $\mathbf{0}$ & 0.032 \\
\hline & CYP2C9*2_430T/C & 75 & 23 & 2 & 72 & 26 & 2 & \\
\hline & CYP2C9*3_1075A/C & 86 & 12 & 2 & 82 & 17 & 1 & \\
\hline & CYP3A4*1B $-392 \mathrm{~A} / \mathrm{G}$ & 91 & 9 & 0 & 95 & 5 & 0 & \\
\hline
\end{tabular}

Those polymorphisms that resulted to be significantly distributed differently in osteosarcoma patients compared to healthy controls are given in bold with their two-sided $p$ values. WT, wild-type; HET, heterozygous; VAR, variant.

was associated also with thrombocytopenia and the necessity of red blood cells or platelet transfusions (Table 7). Likewise for methotrexate cycles, a higher risk for nausea and vomiting was found for patients with WT status of $\mathrm{ABCC} 2$ 3972A/G.

Multiple regression analysis confirmed the predictive value of the $\mathrm{ABCC} 2$ _1249A/G genotype for leukopenia (Table 7).

\section{DISCUSSION}

Although high-grade HGOS is the most common malignant bone tumor in children and adolescents, pharmacogenomic markers still cannot be used for patient stratification or treatment modulation [9]. Since scarce response to multi-drug chemotherapy occurs in about $40 \%$ of HGOS patients, and the four backbone drugs

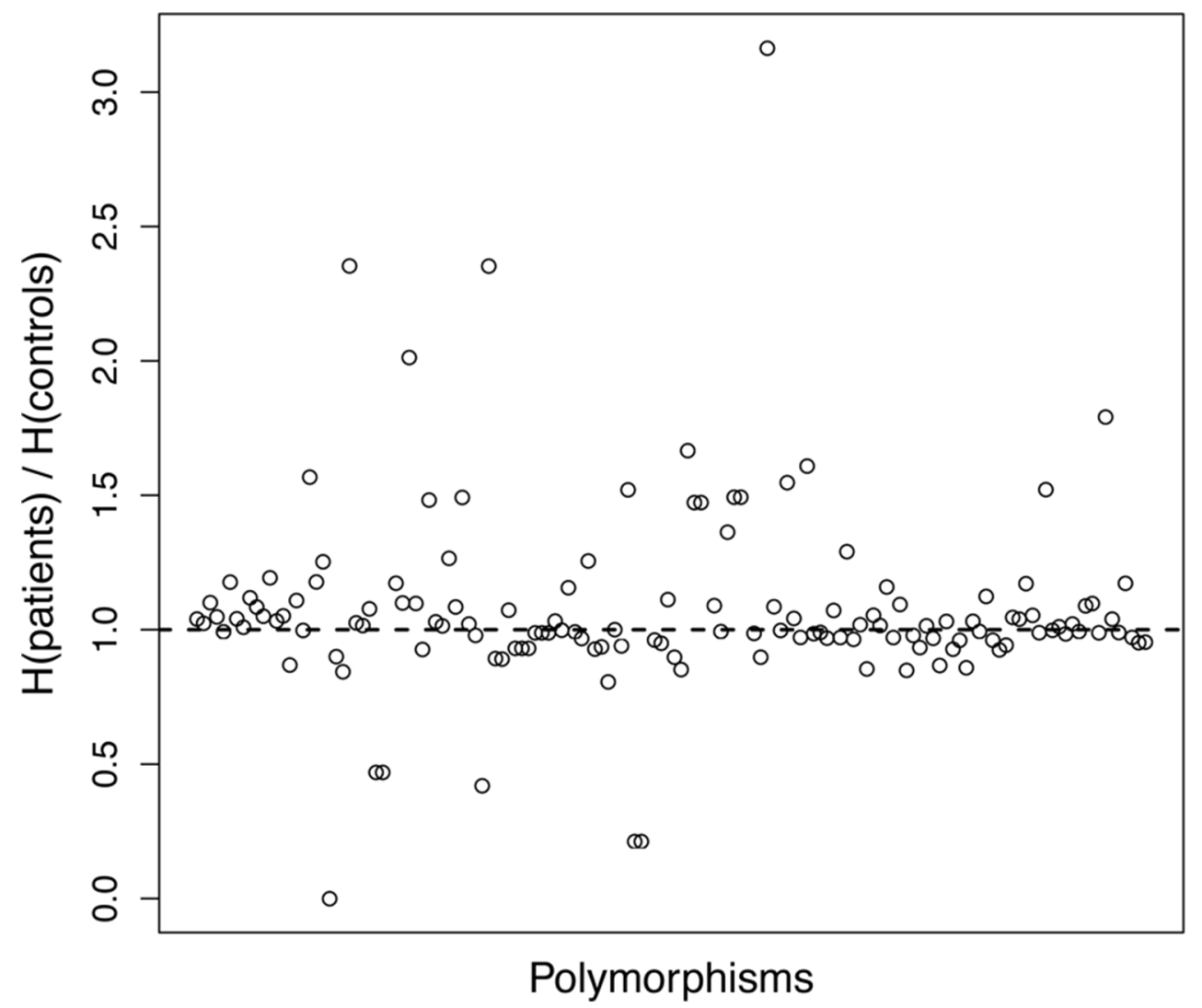

Figure 1: Graphical representation of Shannon entropy. For each polymorphism and each classification type, the ratio of patient and control entropies is plotted. Each circle in the plot represents the ratio between the entropy values of patients and controls for a specific polymorphism. For the sake of readability, the identity of polymorphisms is not reported, as it is not relevant for the purpose of this analysis. 
Table 3: Genotypes significantly associated with increased relative risk to develop osteosarcoma compared to healthy controls identified by logistic regression analysis

\begin{tabular}{|c|c|c|}
\hline $\begin{array}{l}\text { Polymorphism } \\
\text { [risk-associated genotype] }\end{array}$ & OR (CI 95\%) & $p$ \\
\hline $\begin{array}{l}\mathrm{ABCC} 2 \_1249 \mathrm{~A} / \mathrm{G} \\
{[\mathrm{HET}+\mathrm{VAR}]}\end{array}$ & $1.71(1.20-2.43)$ & 0.003 \\
\hline $\begin{array}{l}\text { ABCC2_3972A/G } \\
{[\text { VAR] }}\end{array}$ & $2.24(1.18-4.24)$ & 0.013 \\
\hline $\begin{array}{l}\text { hMLH1_676A/G } \\
{[\text { HET + VAR] }}\end{array}$ & $1.62(1.14-2.31)$ & 0.007 \\
\hline $\begin{array}{l}\text { XPG_3508G/C } \\
\text { [VAR] }\end{array}$ & $2.47(1.36-4.50)$ & 0.003 \\
\hline $\begin{array}{l}\text { GGH_401T/C } \\
{[\text { VAR] }}\end{array}$ & $2.14(1.07-4.69)$ & 0.032 \\
\hline $\begin{array}{l}\text { GGH_16T/C } \\
\text { [VAR] }\end{array}$ & $2.24(1.07-4.69)$ & 0.033 \\
\hline $\begin{array}{l}\text { MTHFR_677T/C } \\
\text { [VAR] }\end{array}$ & $1.68(1.08-2.61)$ & 0.022 \\
\hline $\begin{array}{l}\text { TYMS_28bp_VNTR } \\
{[\mathrm{HET}+\mathrm{VAR}]}\end{array}$ & $1.67(1.18-2.35)$ & 0.004 \\
\hline $\begin{array}{l}\text { MDM2_309T/G } \\
{[\mathrm{HET}+\mathrm{VAR}]} \\
{[\mathrm{VAR}]}\end{array}$ & $\begin{array}{l}1.73(1.22-2.46) \\
2.25(1.46-3.47)\end{array}$ & 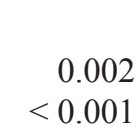 \\
\hline $\begin{array}{l}\text { TP53_IVS2 + 38G/C } \\
{[\mathrm{HET}+\mathrm{VAR}]} \\
{[\mathrm{VAR}]}\end{array}$ & $\begin{array}{c}13.37(7.76-23.03) \\
15.63(10.20-24.39)\end{array}$ & $\begin{array}{l}<0.0001 \\
<0.0001\end{array}$ \\
\hline $\begin{array}{l}\text { TP53_ex4 + 119G/C } \\
\text { [WT] }\end{array}$ & $1.68(1.17-2.41)$ & 0.005 \\
\hline
\end{tabular}

OR, odd ratio; CI, confidence interval; $p$ values refer to the genotype with higher risk which is given in brackets; WT, wild-type; HET, heterozygous; VAR, variant.

of HGOS chemotherapy can cause severe short- and long-time toxic events [10], there is urgent need to identify pharmacogenetic markers that can identify patients with higher risk for unresponsiveness and/or to develop drug-related toxicity.

More than 100 polymorphisms were reported in association with HGOS [4], but few of them were correlated with clinical parameters, survival and the development of toxic events, e.g. [9, 11, 12]. Therefore, we aimed to analyze polymorphisms known to be involved in the pathways of all four drugs used in HGOS chemotherapy in a well documented series of HGOS patients in order to address all these questions at the same time.

We observed 12 polymorphisms associated with an increased risk for HGOS development including five polymorphisms of genes being important in the folate metabolism, two polymorphisms of DNA repair genes, two polymorphisms of the $\mathrm{ABCC} 2$ transporter, and three of the apoptosis pathway. The variant allele of the MDM2_309T/G polymorphism was reported to be associated with sarcomas, including osteosarcoma, by several studies including meta-analyses [13-15]. The wild-type allele of TP53_ex4+119G/C was reported in association with risk of $\mathrm{HGOS}$ in two studies $[16,17]$ but not confirmed in one meta-analysis [13].

With respect to survival-related genotypes, the HET + VAR status of ABCC2_1249A/G, the VAR status of GGH_452T/C and CYP2B 6*6 and the WT + HET status of TP53_IVS2+38G/C were associated with worse EFS. Given that these genes do not belong to the same pathway and are not reciprocally associated, a coevaluation identified three groups with significantly different survival probabilities suggesting that these four polymorphisms have a combined effect on survival. To our knowledge, these polymorphisms have not been reported as prognostic factors in HGOS patients so far, but a similar approach has recently identified five other 
Table 4: Clinical and pathological characteristics of study patients and cohorts included in survival and toxicity analyses

\begin{tabular}{|c|c|c|c|}
\hline Characteristics & $\begin{array}{c}\text { Total cohort } \\
\text { (frequency) } \\
n=196\end{array}$ & $\begin{array}{l}\text { Survival cohort } \\
\text { (frequency) } \\
n=126\end{array}$ & $\begin{array}{l}\text { Toxicity cohort } \\
\text { (frequency) } \\
n=\mathbf{5 7}\end{array}$ \\
\hline \multicolumn{4}{|l|}{ Gender } \\
\hline Male & $122(62 \%)$ & $75(60 \%)$ & $37(65 \%)$ \\
\hline Female & $74(38 \%)$ & $51(40 \%)$ & $20(35 \%)$ \\
\hline \multicolumn{4}{|l|}{ Age } \\
\hline$<14$ years & $60(31 \%)$ & $43(34 \%)$ & $24(42 \%)$ \\
\hline$\geq 14$ years & $136(69 \%)$ & $83(66 \%)$ & $33(58 \%)$ \\
\hline \multicolumn{4}{|l|}{ Site } \\
\hline Femur & $101(51 \%)$ & $75(60 \%)$ & $30(53 \%)$ \\
\hline Tibia & $39(20 \%)$ & $27(21 \%)$ & $15(26 \%)$ \\
\hline Humerus & $23(12 \%)$ & $15(12 \%)$ & $9(16 \%)$ \\
\hline Fibula & $8(4 \%)$ & $5(4 \%)$ & $3(5 \%)$ \\
\hline Other & $25(13 \%)$ & $4(3 \%)$ & $0(0 \%)$ \\
\hline \multicolumn{4}{|l|}{ Metastasis at diagnosis } \\
\hline Absent & $179(91 \%)$ & $126(100 \%)$ & $57(100 \%)$ \\
\hline Present & $17(9 \%)$ & $0(0 \%)$ & $0(0 \%)$ \\
\hline \multicolumn{4}{|l|}{ Histologic Subtype } \\
\hline Osteoblastic & $125(64 \%)$ & $88(70 \%)$ & $43(75 \%)$ \\
\hline Fibroblastic & $24(12 \%)$ & $19(15 \%)$ & $6(11 \%)$ \\
\hline Chondroblastic & $18(9 \%)$ & $14(11 \%)$ & $7(12 \%)$ \\
\hline Telangiectatic & $3(2 \%)$ & $2(2 \%)$ & $1(2 \%)$ \\
\hline Not specified & $22(11 \%)$ & $3(2 \%)$ & $0(0 \%)$ \\
\hline Irradiation-induced & $4(2 \%)$ & $0(0 \%)$ & $0(0 \%)$ \\
\hline \multicolumn{4}{|l|}{ Surgery } \\
\hline Yes & $194(99 \%)$ & $126(100 \%)$ & $57(100 \%)$ \\
\hline No & $2(1 \%)$ & $0(0 \%)$ & $0(0 \%)$ \\
\hline \multicolumn{4}{|l|}{ Treatment } \\
\hline Adjuvant $^{\mathrm{a}}$ & $16(8 \%)$ & $0(0 \%)$ & $0(0 \%)$ \\
\hline Neo-adjuvant $\mathrm{t}^{\mathrm{b}}$ & $171(87 \%)$ & $126(100 \%)$ & $57(100 \%)$ \\
\hline No chemotherapy & $9(5 \%)$ & $0(0 \%)$ & $0(0 \%)$ \\
\hline
\end{tabular}

aTreatment including doxorubicin, cisplatin and methotrexate.

${ }^{b}$ Treatment including doxorubicin, cisplatin, methotrexate and ifosfamide.

polymorphisms with combined effect on EFS [18]. On the other hand, several studies reported polymorphisms associated with survival that were analyzed also in our study, although they did not reveal any prognostic impact (e.g. ABCB1_1236T/C [11], drug-metabolizing enzymes [19]). The observation that different polymorphisms can impact similarly on EFS could be explained by the genomic complexity and heterogeneity of HGOS, by the different drugs used for treatment, nonetheless by the small number of overlapping polymorphisms analyzed in the different studies.

Doxorubicin, methotrexate and cisplatin are known substrates of $\mathrm{ABCC} 2$ and this protein was the third most expressed $\mathrm{ABC}$ transporter in a series of HGOS cell lines [20], although $\mathrm{ABCB} 1$ is the best described biological prognostic marker in HGOS [3]. Polymorphisms of
$A B C C 2$ are known to influence the bioavailability of drugs and therefore could contribute to a reduced chemotherapy efficacy [21, 22].

GGH catalyzes the removal of polyglutamates, preferencially from long-chain methotrexate polyglutamates, thus influencing the overall effectiveness of methotrexate [23]. The VAR status of GGH_452T/C was found in children with acute lymphoblastic leukemia who showed exclusively low or intermediate catalytic activity of GGH with the consequence of intracellular accumulation of long-chain methotrexate polyglutamates [24].

Our data suggest that in HGOS this polymorphism plays a different role, since they indicated that the VAR status of GGH_452T/C might reduce the effectiveness of methotrexate treatment in HGOS patients. It would be 
Table 5: Genotype frequencies in the subgroups of osteosarcoma patients eligible for survival (survival cohort) and toxicity (toxicity cohort) analyses

\begin{tabular}{|c|c|c|c|c|c|c|c|}
\hline \multirow[b]{2}{*}{ Main gene function } & \multirow[b]{2}{*}{ Polymorphism } & \multicolumn{3}{|c|}{$\begin{array}{l}\text { Survival cohort } \\
(n=126 \text { patients })\end{array}$} & \multicolumn{3}{|c|}{$\begin{array}{l}\text { Toxicity cohort } \\
(n=57 \text { patients })\end{array}$} \\
\hline & & WT (\%) & HET (\%) & VAR (\%) & WT (\%) & HET (\%) & VAR (\%) \\
\hline \multirow{9}{*}{ 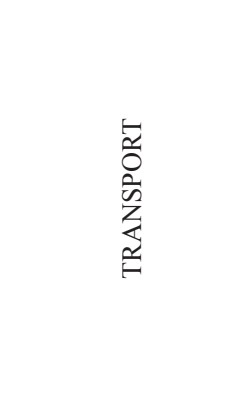 } & ABCB1_3435T/C & 29 & 44 & 27 & 33 & 44 & 23 \\
\hline & ABCB1_1236T/C & 31 & 46 & 23 & 29 & 51 & 20 \\
\hline & ABCB1_2677G/T/A & 27 & 46 & 27 & 21 & 49 & 30 \\
\hline & ABCC2_1249A/G & 49 & 48 & 3 & 54 & 44 & 2 \\
\hline & $\mathrm{ABCC} 2 \_-24 \mathrm{~A} / \mathrm{G}$ & 59 & 37 & 4 & 57 & 39 & 4 \\
\hline & ABCC2_3972A/G & 48 & 35 & 17 & 37 & 41 & 22 \\
\hline & ABCG2_34A/G & 85 & 15 & 0 & 91 & 9 & 0 \\
\hline & ABCG2_421A/C & 82 & 16 & 2 & 85 & 15 & 0 \\
\hline & RFC_80A/G & 37 & 46 & 17 & 37 & 51 & 12 \\
\hline \multirow{11}{*}{ 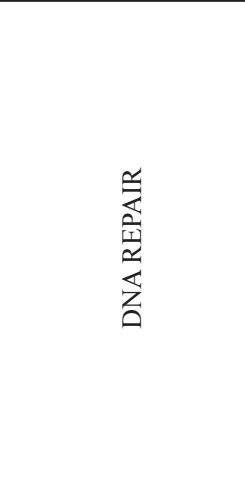 } & APE1_2197T/G & 18 & 47 & 35 & 16 & 52 & 32 \\
\hline & ERCC1_8092T/G & 60 & 34 & 6 & 60 & 38 & 2 \\
\hline & ERCC1_19007T/C & 30 & 46 & 24 & 26 & 56 & 18 \\
\hline & hMLH1_676A/G & 37 & 51 & 12 & 36 & 51 & 13 \\
\hline & hMSH2 IVS12-6T/C & 89 & 11 & 0 & 89 & 11 & 0 \\
\hline & hOGG1 $1245 \mathrm{C} / \mathrm{G}$ & 64 & 28 & 8 & 68 & 25 & 7 \\
\hline & XPD_35931T/G & 38 & 49 & 13 & 37 & 52 & 11 \\
\hline & XPD_23591A/G & 40 & 47 & 13 & 39 & 52 & 9 \\
\hline & XPG_3508G/C & 57 & 31 & 12 & 65 & 30 & 5 \\
\hline & XRCC1 $28152 \mathrm{~A} / \mathrm{G}$ & 42 & 46 & 12 & 35 & 49 & 16 \\
\hline & XRCC3 $18067 \mathrm{~T} / \mathrm{C}$ & 30 & 55 & 15 & 27 & 58 & 15 \\
\hline \multirow{11}{*}{ 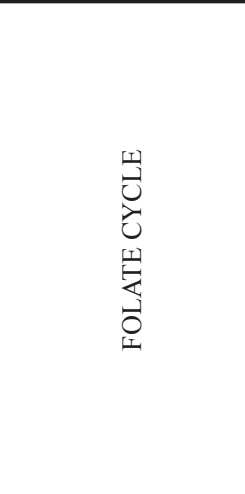 } & DHFR_Ins/Del & 38 & 46 & 16 & 30 & 52 & 18 \\
\hline & FOLR1_181delC & 94 & 6 & 0 & 98 & 2 & 0 \\
\hline & GGH_452T/C & 82 & 15 & 3 & 83 & 12 & 5 \\
\hline & GGH_401T/C & 49 & 35 & 16 & 55 & 29 & 16 \\
\hline & GGH_16T/C & 61 & 24 & 15 & 66 & 19 & 15 \\
\hline & MTHFD1_1958T/C & 28 & 55 & 17 & 27 & 57 & 16 \\
\hline & MTHFR_677T/C & 31 & 52 & 17 & 33 & 51 & 16 \\
\hline & MTHFR_1298A/C & 41 & 49 & 10 & 39 & 50 & 11 \\
\hline & SHMT_1420T/C & 53 & 40 & 7 & 50 & 41 & 9 \\
\hline & TYMS_28bp_VNTR & 39 & 43 & 18 & 30 & 47 & 23 \\
\hline & TYMS_1494del6 & 33 & 53 & 14 & 30 & 54 & 16 \\
\hline \multirow{7}{*}{ 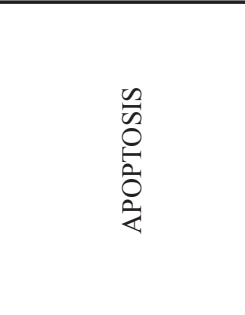 } & ATM_40C/G & 98 & 2 & 0 & 98 & 2 & 0 \\
\hline & ATM_61A/G & 72 & 26 & 2 & 73 & 25 & 2 \\
\hline & MDM2_309T/G & 30 & 50 & 20 & 28 & 47 & 25 \\
\hline & p21 $98 \mathrm{~A} / \mathrm{C}$ & 87 & 13 & 0 & 93 & 7 & 0 \\
\hline & TP53 PIN3 IVS3 + 16 bp & 66 & 29 & 5 & 63 & 35 & 2 \\
\hline & TP53_IVS2+38G/C & 7 & 35 & 58 & 9 & 34 & 57 \\
\hline & TP53 ex4+119G/C & 66 & 27 & 7 & 70 & 21 & 9 \\
\hline \multirow{9}{*}{ 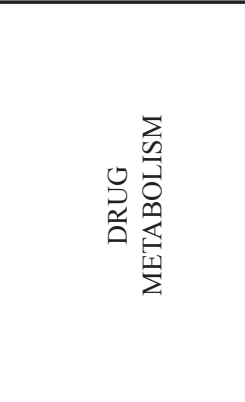 } & GSTT1_gen_null & 83 & 0 & 17 & 88 & 0 & 12 \\
\hline & GSTM1_gen_null & 42 & 0 & 58 & 39 & 0 & 61 \\
\hline & GSTP1_313A/G & 52 & 42 & 6 & 54 & 44 & 2 \\
\hline & CYP2C19*2_681A/G & 75 & 24 & 1 & 72 & 26 & 2 \\
\hline & CYP2B6*6 & 65 & 29 & 6 & 68 & 25 & 7 \\
\hline & CYP2B6*7 & 99 & 1 & 0 & 100 & 0 & 0 \\
\hline & CYP2C9*2_430T/C & 73 & 26 & 1 & 68 & 32 & 0 \\
\hline & CYP2C9*3_1075A/C & 86 & 11 & 3 & 91 & 9 & 0 \\
\hline & CYP3A4*1B_-392A/G & 90 & 10 & 0 & 89 & 11 & 0 \\
\hline
\end{tabular}

WT, wild-type; HET, heterozygous; VAR, variant. 
therefore interesting to analyze whether the GGH_452T/C variant affects the hydrolytic activity of this enzyme also in HGOS cells.

Since the VAR status of CYP2B6*6 was described to result in decreased expression and activity of this enzyme in liver cells $[8,25]$, patients with HGOS might be less responsive to ifosfamide, which is activated by CYP2B6.
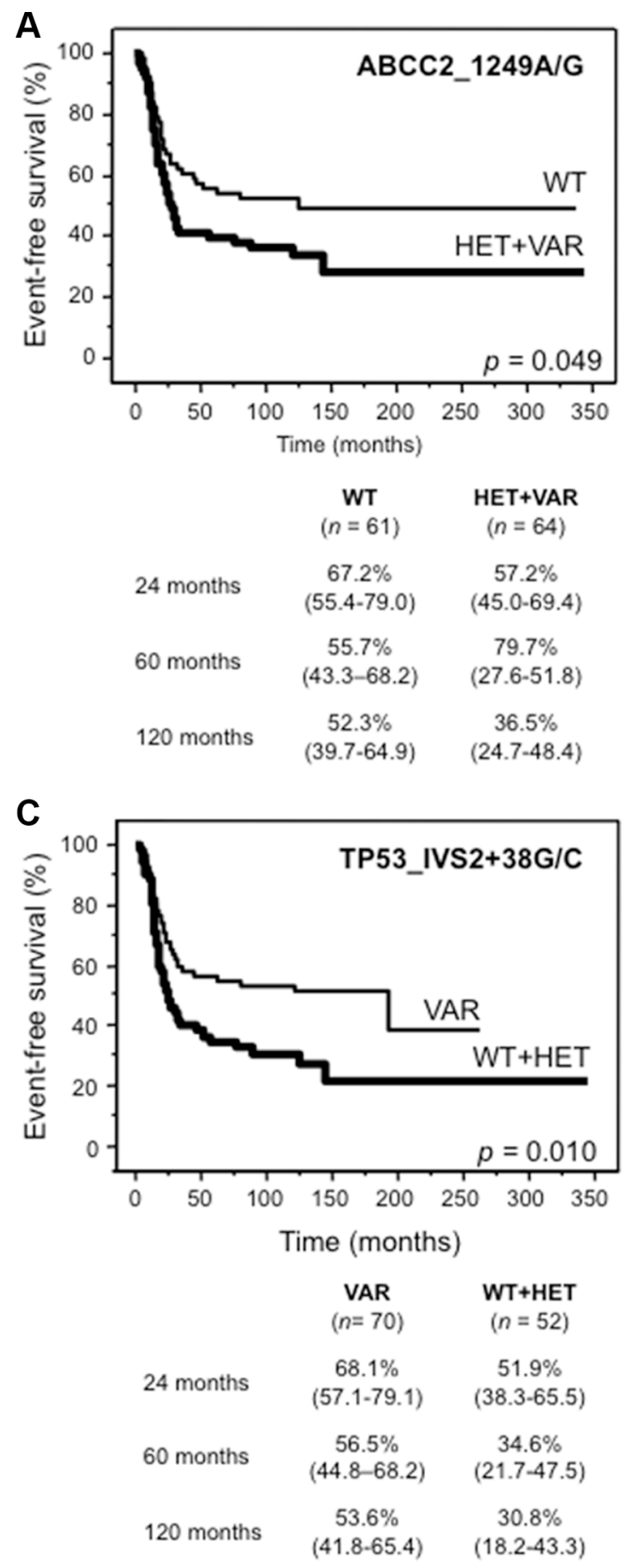

Regarding the role of TP53_IVS2+38G/C, we hypothesize that although the VAR status is associated with a high risk for HGOS development, patients seem to respond better to treatment and therefore have a higher probability of EFS compared to those with WT + HET status. However, these four polymorphisms were not associated with necrosis evaluated after pre-operative
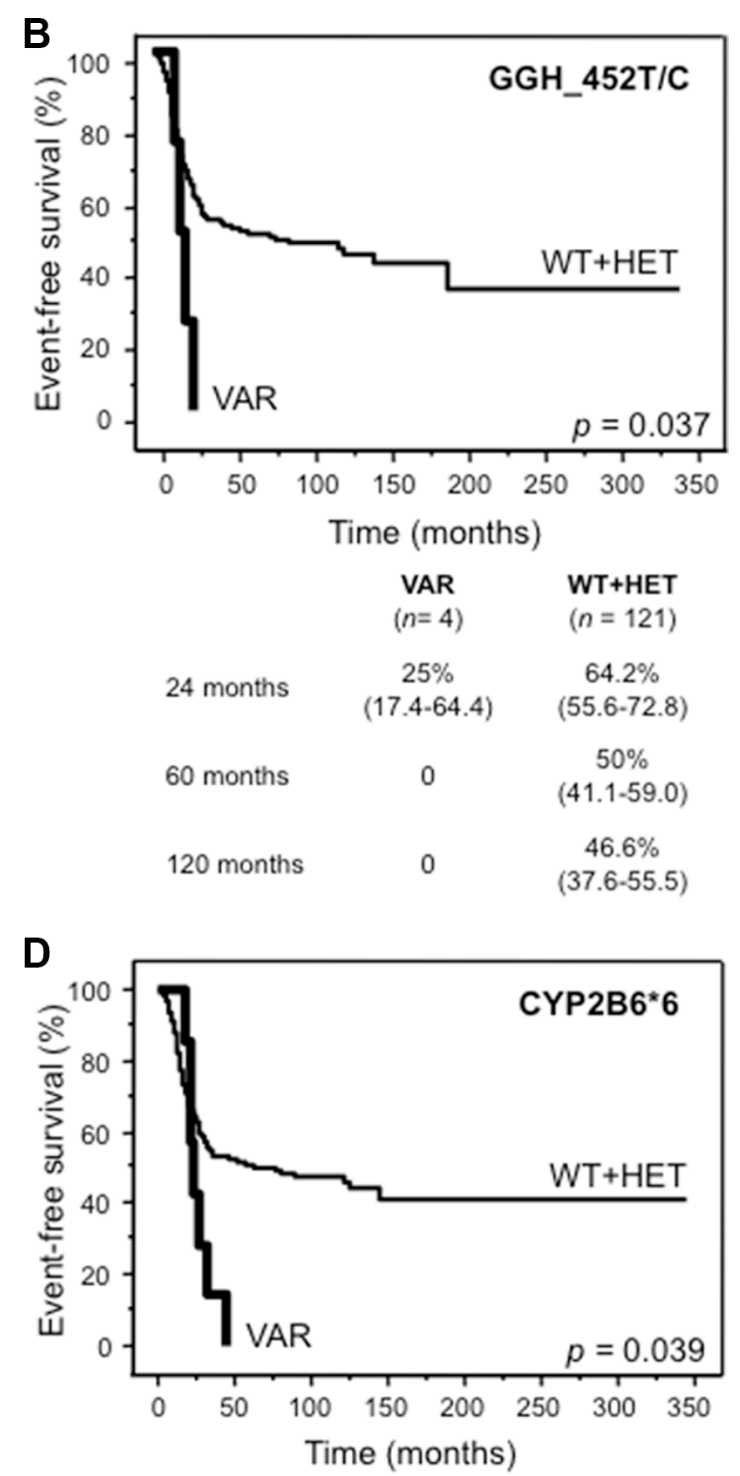

$\begin{array}{lcc} & \begin{array}{c}\text { VAR } \\ (n=7)\end{array} & \begin{array}{c}\text { WT+HET } \\ (n=113)\end{array} \\ & 42.9 \% & 64.3 \% \\ 24 \text { months } & (6.2-79.5) & (55.4-73.2) \\ & & 50.9 \% \\ 60 \text { months } & 0 & (41.7-60.2) \\ & & 47.3 \% \\ 120 \text { months } & 0 & (38.0-56.6)\end{array}$

Figure 2: Kaplan Meier curves for the four genotypes significantly influencing event-free survival in univariate analysis. (A) ABCC2_1249A/G (rs2273697), (B) GGH_452T/C (rs11545078), (C) TP53_IVS2+38G/C (rs1642785) and (D) CYP2B6*6. For each genotype, tables show survival probabilities in \% with $95 \%$ confidence interval in parenthesis at 24, 60 and 120 months for both categories. $n$, number of patients; WT, wild-type; HET + VAR, heterozygous + variant; WT + HET, wild-type + heterozygous; VAR, variant. 
chemotherapy (data not shown) and differed from those described in other studies $([12,18]$, drug-metabolizing enzymes, for review see [19]). Therefore the direct impact on survival needs still to be elucidated.

Among the polymorphisms associated with hematological toxicity, the HET + VAR status of ABCC2_1249A/G was associated with leukopenia and thrombocytopenia grade 4 and the necessity of red blood cells and platelet transfusion. This association remained significant even in multiple regression analysis and was associated prevalently to doxorubicin/cisplatin/ifosfamide treatment which can be ascribed to the fact that both doxorubicin and cisplatin are substrates of ABCC2.

Another variant associated with leukopenia grade 4 was the HET + VAR status of MTHFR_1298A/C, which was reported in association with anemia after methotrexate cycles in HGOS patients [12].

Hepatotoxicity was associated with the WT status of $\mathrm{ABCC} 21249 \mathrm{~A} / \mathrm{G}$ and $\mathrm{GGH} 16 \mathrm{~T} / \mathrm{C}$ and with the $\mathrm{HET}+\overline{\mathrm{VAR}}$ status of $\mathrm{ABCB} 1$ 1 1236T/C. All three polymorphisms remained significant by multiple regression analyses in relation to the complete treatment and to the methotrexate administration.
Since polymorphisms of ABC-transporters are known to influence the bioavailability of several drugs [26], and methotrexate is substrate of ABCB1 and $A B C C 2$, our findings suggest that the variant allele of ABCB1_1236T/C increases toxicity in hepatic cells due to a lower activity of the enzyme. Conversely, the variant allele of ABCC2_1249A/G is protective. Since there are no pharmacokinetic studies available in HGOS patients these assumptions need confirmation by functional studies.

To our knowledge, the functional role of GGH_16T/C polymorphism is still unknown. Our observation suggests that WT status could be associated with higher accumulation of methotrexate long chain polyglutamates, thus increasing cytotoxicity in hepatic cells.

Independently of the administered drugs, WT status of ABCC2_3972A/G was associated with nausea and vomiting. The mechanism underlying this association has yet to be elucidated since no data were reported.

A peculiar feature of this study was the application of the information-theoretical measures Shannon entropy and cluster analysis to genotyping data to support the interpretation of polymorphism distributions in patients

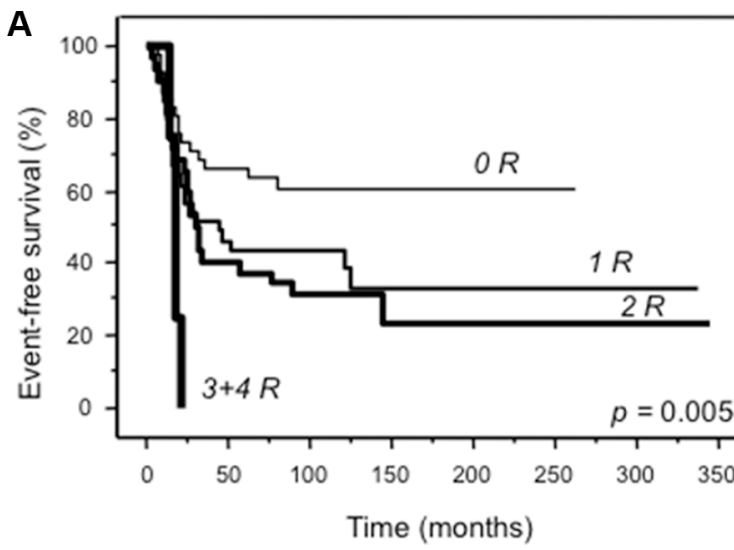

$\begin{array}{lcccc} & \begin{array}{c}\mathbf{0 ~ R} \\ (n=41)\end{array} & \begin{array}{c}1 \mathbf{R} \\ (n=40)\end{array} & \begin{array}{c}\text { 2 R } \\ (n=32)\end{array} & \begin{array}{c}3+4 \mathbf{R} \\ (n=4)\end{array} \\ 24 & 73.2 \% & 56.5 \% & 65.6 \% & \\ \text { months } & (59.6-86.7) & (41-72.1) & (49.2-82.1) & 0 \\ 60 & 65.9 \% & 43.7 \% & 37.5 \% & \\ \text { months } & (51.3-80.4) & (28.1-59.3) & (20.7-54.3) & 0 \\ 120 & 60.9 \% & 43.7 \% & 31.2 \% & \\ \text { months } & (45.9-75.8) & (28.1-59.3) & (15.2-47.3) & 0\end{array}$

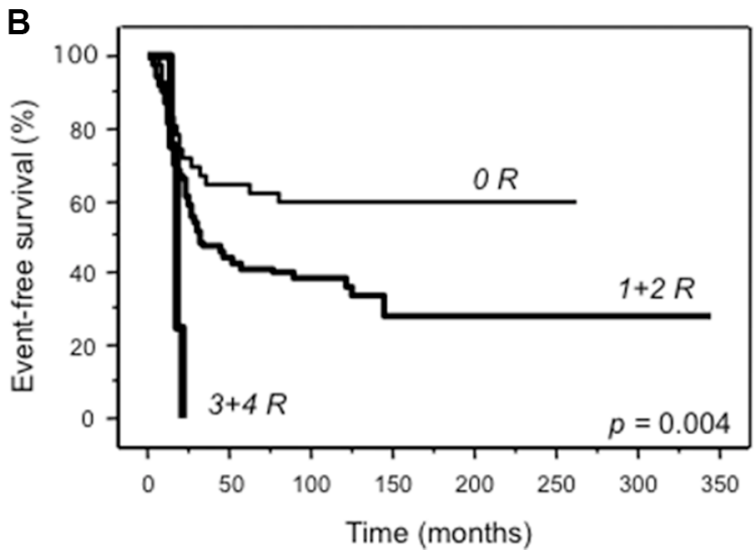

$\begin{array}{cccc} & \begin{array}{c}\text { R } \\ (n=41)\end{array} & \begin{array}{c}1+2 \mathrm{R} \\ (n=72)\end{array} & \begin{array}{c}3+4 \mathbf{R} \\ (n=4)\end{array} \\ & & & \\ 24 \text { months } & 71.4 \% & 61.5 \% & 0 \\ & (57.8-85.1) & (50.1-72.9) & 0 \\ 60 \text { months } & 64.3 \% & 41.5 \% & \\ & (49.8-78.8) & (29.9-53) & 0 \\ 120 \text { months } & 59.4 \% & 38.6 \% & \\ & (44.5-74.3) & (27.2-50) & 0\end{array}$

Figure 3: Kaplan Meier curves of event-free survival for 117 patients assigned to four (A) or three (B) risk groups defined by the presence of none, 1, 2, 3 or 4 risk genotypes of ABCC2_1249A/G (rs2273697), GGH_452T/C (rs11545078), TP53_IVS2+38G/C (rs1642785) and CYP2B6*6. For each risk group (0 R, 1 R, 2 R, $3+4$ R), tables show survival probabilities in $\%$ with $95 \%$ confidence interval in parenthesis at 24,60 and 120 months for all categories. $n$, number of patients. 
Table 6: Toxic events associated with genotypes in 57 osteosarcoma patients and relative risk estimation by logistic regression analyses

\begin{tabular}{|c|c|c|c|c|c|c|c|}
\hline \multirow[b]{2}{*}{ Toxic events } & \multirow{2}{*}{$\begin{array}{c}\text { Frequency of } \\
\text { toxic events }\end{array}$} & \multirow[b]{2}{*}{ Polymorphism } & \multirow[b]{2}{*}{$\begin{array}{c}p \\
\text { (Fisher's Test) }\end{array}$} & \multicolumn{2}{|c|}{ Univariate logistic regression } & \multicolumn{2}{|c|}{ Multivariate logistic regression } \\
\hline & & & & OR $(95 \% \mathrm{CI})$ & $p$ & $\begin{array}{c}\text { Adjusted } \\
\text { OR }(95 \% \text { CI) }\end{array}$ & $p$ \\
\hline \multirow[t]{2}{*}{ Leukopenia grade 4} & $79 \%$ & $\begin{array}{l}\mathrm{ABCC} 2 \_1249 \mathrm{~A} / \mathrm{G} \\
{[\mathrm{HET}+\mathrm{VAR}]}\end{array}$ & 0.007 & $13.16(1.56-111.12)$ & 0.018 & $10.20(1.17-90.90)$ & 0.035 \\
\hline & & $\begin{array}{l}\text { MTHFR_1298A/C } \\
{[\text { HET + VAR }]}\end{array}$ & 0.047 & $4.15(1.06-16.13)$ & 0.040 & $2.93(0.69-12.50)$ & 0.145 \\
\hline \multirow[t]{2}{*}{$\begin{array}{l}\text { Thrombocytopenia } \\
\text { grade } 4\end{array}$} & $68 \%$ & $\begin{array}{l}\mathrm{ABCC} 2 \_1249 \mathrm{~A} / \mathrm{G} \\
{[\mathrm{HET}+\mathrm{VAR}]}\end{array}$ & 0.024 & $4.33(1.20-15.63)$ & 0.025 & $23.81(2.50-250.00)$ & 0.006 \\
\hline & & $\begin{array}{l}\text { XPD_23591A/G } \\
{[\mathrm{HET}+\mathrm{VAR}]}\end{array}$ & 0.004 & $5.59(1.66-18.87)$ & 0.006 & $27.78(3.10-250.00)$ & 0.003 \\
\hline $\begin{array}{l}\text { Red blood cells } \\
\text { transfusion }\end{array}$ & $54 \%$ & $\begin{array}{l}\mathrm{ABCC} 2 \_1249 \mathrm{~A} / \mathrm{G} \\
{[\mathrm{HET}+\mathrm{VAR}]}\end{array}$ & 0.002 & $6.06(1.88-19.60)$ & 0.003 & & \\
\hline Platelet transfusion & $39 \%$ & $\begin{array}{l}\mathrm{ABCC} 2 \_1249 \mathrm{~A} / \mathrm{G} \\
{[\mathrm{HET}+\mathrm{VAR}]}\end{array}$ & 0.030 & $3.36(1.10-10.20)$ & 0.033 & & \\
\hline Fever & $70 \%$ & $\begin{array}{l}\text { ERCC1_8092T/G } \\
{[\mathrm{HET}+\mathrm{VAR}]}\end{array}$ & 0.016 & $6.49(1.30-32.26)$ & 0.023 & & \\
\hline \multirow[t]{2}{*}{ Nausea/Vomiting } & $44 \%$ & $\begin{array}{l}\mathrm{ABCC} 2 \_3972 \mathrm{~A} / \mathrm{G} \\
{[\mathrm{WT}]}\end{array}$ & 0.001 & $8.33(2.35-29.58)$ & 0.001 & $5.85(1.57-21.85)$ & 0.009 \\
\hline & & $\begin{array}{l}\text { XRCC3_18067T/C } \\
{[\mathrm{HET}+\mathrm{VAR}]}\end{array}$ & 0.037 & $4.42(1.08-18.18)$ & 0.039 & $3.22(0.56-18.52)$ & 0.188 \\
\hline \multirow{3}{*}{$\begin{array}{l}\text { Hepatotoxicity } \\
\text { (Transaminases } \\
\text { grade 4) }\end{array}$} & $56 \%$ & $\begin{array}{l}\mathrm{ABCB} 1 \_1236 \mathrm{~T} / \mathrm{C} \\
{[\mathrm{HET}+\mathrm{VAR}]}\end{array}$ & 0.047 & $2.06(1.16-3.66)$ & 0.014 & $2.28(1.23-4.26)$ & 0.009 \\
\hline & & $\begin{array}{l}\mathrm{ABCC} 2 \_1249 \mathrm{~A} / \mathrm{G} \\
{[\mathrm{WT}]}\end{array}$ & 0.050 & $1.96(1.20-3.20)$ & 0.007 & $1.83(1.10-3.05)$ & 0.021 \\
\hline & & $\begin{array}{l}\text { GGH_16T/C } \\
{[\mathrm{WT}]}\end{array}$ & 0.025 & $2.87(1.53-5.41)$ & 0.001 & $2.95(1.56-5.59)$ & 0.001 \\
\hline
\end{tabular}

OR, odd ratio; CI, confidence intervals; WT, wild-type; HET + VAR, heterozygous + variant; $p$ values refer to the genotype with higher risk which is given in brackets.

and healthy controls by objective means. It is noteworthy, that among the eleven polymorphisms with $r>1.5$, four were associated with risk to develop HGOS, three with impact on survival, and two with toxicity.

In order to obtain information regarding the potential functional effects of the polymorphisms analyzed in the present study, two web-based SNP bioinformatic tools were explored to predict their regulatory potential, as indicated by specific in silico scores $(<\mathrm{https} / / /$ snpinfo. niehs.nih.gov/snpinfo/snpfunc.htm>; $\quad<$ http://compbio. cs.queensu.ca/F-SNP/ $>$ and references therein). Several of the polymorphisms that resulted to be associated with survival, toxicity and/or risk for HGOS in this study also showed scores $>0.5$ that indicated a relevant functional impact. This group included three polymorphisms associated with survival (ABCC2_1249A/G, GGH_452T/C, CYP2B6*6), seven associated with toxicity (ABCC2_1249A/G, ABCC2_3972A/G, ERCC1_8092T/G, XPD 23591A/G， XRCC 3 $18067 \mathrm{~T} / \mathrm{C}, \mathrm{GGH} 16 \mathrm{~T} / \mathrm{C}$, MTHFR_1298A/C), and three associated with risk for HGOS (ABCC2_1249A/G, ABCC2_3972A/G,
GGH_16T/C). This evidence indicates that the polymorphisms emerged in our study as associated to survival, toxicity and/or risk for HGOS also have a predicted relevant functional impact, which however needs to be explored and confirmed in further functional studies.

In summary, since the ABCC2 1249A/G polymorphism was associated with risk of HGOS development, worse EFS and hematological toxicity, and presented a relevant predicted functional impact, it should be prioritized for further validation studies in order to definitely estimate its relevance for a possible use as patients stratification marker. Furthermore, our data indicate to consider in addition to ABCC2_1249A/G, also TP53_IVS2+38G/C, GGH_452T/C and CYP2B6*6 in a prospective screening because of their demonstrated prognostic value. ABCB1_1236T/C, ABCC2_3972A/G, XPD_23591A/G, ERCC1_8092T/G, XRCC3_18067T/C, MTHFR_1298A/C, GGH_16T/C polymorphisms should be further validated within a prospective trial with registered toxic events to fully determine their value as markers for patient stratification. 
Table 7: Toxic events significantly associated with genotypes in relation to methotrexate or doxorubicin, cisplatin and ifosfamide by logistic regression analyses

\begin{tabular}{|c|c|c|c|c|c|c|}
\hline \multirow{2}{*}{$\begin{array}{l}\text { Drug } \\
\text { (cycles) }\end{array}$} & \multirow{2}{*}{ Toxic events } & \multirow{2}{*}{ Polymorphism } & \multicolumn{2}{|c|}{ Univariate logistic regression } & \multicolumn{2}{|c|}{ Multivariate logistic regression } \\
\hline & & & OR $(95 \%$ CI $)$ & $p$ & $\begin{array}{c}\text { Adjusted } \\
\text { OR }(95 \% \mathrm{CI})\end{array}$ & $p$ \\
\hline \multirow[t]{4}{*}{$\begin{array}{l}\text { Methotrexate } \\
(n=520)\end{array}$} & Nausea/Vomiting & $\begin{array}{l}\mathrm{ABCC} 233972 \mathrm{~A} / \mathrm{G} \\
{[\mathrm{WT}]}\end{array}$ & $3.15(1.06-9.37)$ & 0.039 & & \\
\hline & $\begin{array}{l}\text { Hepatotoxicity } \\
\text { (Transaminases grade 4) }\end{array}$ & $\begin{array}{l}\text { ABCB1_1236T/C } \\
{[\mathrm{HET}+\mathrm{VAR}]}\end{array}$ & $2.21(1.22-4.00)$ & 0.009 & $2.46(1.29-4.72)$ & 0.001 \\
\hline & & $\begin{array}{l}\mathrm{ABCC} 2 \_1249 \mathrm{~A} / \mathrm{G} \\
{[\mathrm{WT}]}\end{array}$ & $2.48(1.47-4.18)$ & 0.001 & $2.28(1.31-3.96)$ & 0.004 \\
\hline & & $\begin{array}{l}\text { GGH_16T/C } \\
{[\mathrm{WT}]}\end{array}$ & $2.93(1.53-5.62)$ & 0.001 & $3.05(1.57-5.92)$ & 0.001 \\
\hline \multirow{6}{*}{$\begin{array}{l}\text { Doxorubicin/ Cisplatin/ } \\
\text { Ifosfamide } \\
(n=488)\end{array}$} & Leukopenia grade 4 & $\begin{array}{l}\mathrm{ABCC} 2 \_1249 \mathrm{~A} / \mathrm{G} \\
{[\mathrm{HET}+\mathrm{VAR}]}\end{array}$ & $2.80(1.63-4.83)$ & $<0.001$ & $2.19(1.23-3.92)$ & 0.008 \\
\hline & & $\begin{array}{l}\text { MTHFR_1298A/C } \\
{[\text { HET + VAR] }}\end{array}$ & $2.19(1.26-3.82)$ & 0.006 & $1.75(0.97-3.13)$ & 0.063 \\
\hline & Thrombocytopenia grade 4 & $\begin{array}{l}\mathrm{ABCC} 2 \_1249 \mathrm{~A} / \mathrm{G} \\
{[\mathrm{HET}+\mathrm{VAR}]}\end{array}$ & $4.35(2.17-8.77)$ & $<0.0001$ & & \\
\hline & Red blood cells transfusion & $\begin{array}{l}\mathrm{ABCC} 2 \_1249 \mathrm{~A} / \mathrm{G} \\
{[\mathrm{HET}+\mathrm{VAR}]}\end{array}$ & $2.13(1.12-4.07)$ & 0.022 & & \\
\hline & Platelet transfusion & $\begin{array}{l}\mathrm{ABCC} 2 \_1249 \mathrm{~A} / \mathrm{G} \\
{[\mathrm{HET}+\mathrm{VAR}]}\end{array}$ & $3.55(1.59-7.87)$ & 0.002 & & \\
\hline & Nausea/Vomiting & $\begin{array}{l}\mathrm{ABCC} 2 \_3972 \mathrm{~A} / \mathrm{G} \\
{[\mathrm{WT}]}\end{array}$ & $2.28(1.02-5.07)$ & 0.045 & & \\
\hline
\end{tabular}

OR, Odd ratio; CI: confidence interval; $p$ values refer to the genotype with higher risk which is given in brackets; WT, wild-type; HET + VAR, heterozygous + variant.

\section{MATERIALS AND METHODS}

\section{Patients and study design}

A total of 196 patients with newly diagnosed HGOS (all recruited and treated at the Rizzoli Orthopaedic Institute, Bologna, Italy between 1984 and 2005) (Table 4) and 470 healthy controls (individuals without cancer at the time of enrollment, who were recruited at the National Cancer Institute, Aviano, Italy) were considered in order to identify polymorphisms associated with the development of HGOS (Figure 4). In order to match as much as possible the healthy controls to the patients cohort, all individuals over 40 years were excluded from the original pool of 1,000 healthy individuals. After this step, the control group showed a male/female ratio (1.55) and a median age (33 years) that were as close as possible to those of the patient cohort (male/female ratio: 1.65; median age 16 years). All individuals were of Caucasian ethnicity and had signed an informed consent. The study was approved by the institutional ethical review boards.

The impact of polymorphisms on clinical outcome was evaluated in a subgroup of 126 patients with conventional HGOS (high-grade tumor of the extremities, non-metastatic at diagnosis, arisen in patients younger than 40 years) treated with standard neoadjuvant chemotherapy protocols based on doxorubicin, high-dose methotrexate, cisplatin and ifosfamide in association to surgery ("survival cohort"). Median follow-up of the survival cohort was 126 months (range 73-345 months).

From this cohort of 126 patients, toxicity data were available for 57 patients ("toxicity cohort") treated according to the ISG/OS-1 protocol [27]. Median follow-up of the toxicity cohort was 118 months (range 73-142 months). Toxicity assessment was performed before each chemotherapy cycle and graded from 0 to 4 according to Common Terminology Criteria for Adverse Events (CTCAE) v4.0.

\section{DNA isolation and polymorphism screening}

Genomic DNA was extracted from frozen lymphocytes obtained from peripheral blood samples or normal muscular tissue using the High Pure PCR Template Preparation Kit (Roche Diagnostics GmbH, Mannheim, Germany). DNA quality and concentration were checked by spectrophotometry using the NanoDrop ND-1000 (NanoDrop Technologies, Wilmington, DE, USA). 
Based on literature search (www.ncbi.nlm.nih. gov/pubmed), 45 polymorphisms and two haplotypes of 31 genes involved in transport, metabolism, activation and detoxification of the four drugs used in standard HGOS chemotherapy (methotrexate, doxorubicin, cisplatin and ifosfamide), as well as in apoptosis or DNA repair were selected for genotyping (Table 1).

Pyrosequencing (Biotage, Uppsala, Sweden), TaqMan genotyping with pre-designed SNP assays (Applied Biosystem, Foster City, CA, USA), PCR or restriction fragment length polymorphism (RFLP) analysis were performed as described (Table 8). Primer sequences and genotyping reaction details are available on request.

\section{Statistical analysis}

Descriptive frequencies are provided for all variables in the data sets of the three cohorts. Hardy-Weinberg equilibrium was assessed by standard methods for each polymorphism in both the healthy controls and total patients cohort. No deviations were found in the healthy controls, whereas few deviations were found in the total patients cohort (Table 1). However, these polymorphisms were not excluded from the study because these deviations may originate from their biological impact in HGOS.
Pairwise linkage disequilibrium (LD) analyses for polymorphisms affecting the same gene were carried out by using the freely available LDPlotter software in both healthy controls and total patients cohort. Strong LD (with $\mathrm{D}^{\prime}>0.95$ and $\mathrm{r}^{2}>0.75$ ) was found only for the polymorphisms of GGH in both healthy controls and total patient cohort.

The Shannon entropy of the distribution of each polymorphism was computed in both the cohorts, patients and controls. Missing values were assigned a special symbol, which was then added to the alphabet of symbols used to denote the specific instance of each polymorphism.

The cluster index $[31,32]$ was computed to identify genotype groups within the same pathway (transport, DNA repair, folate cycle, apoptosis or detoxification) that behaved similarly in HGOS patients compared to healthy controls. Detailed description of the Shannon entropy and cluster index analyses are provided in the Supplementary_Information File.

Two-tailed Fisher's exact or chi-square tests were used to correlate genotypes with clinical and biological parameters and to evaluate statistical associations between different variables. Two-sided $p$ values $<0.05$ were considered as significant.

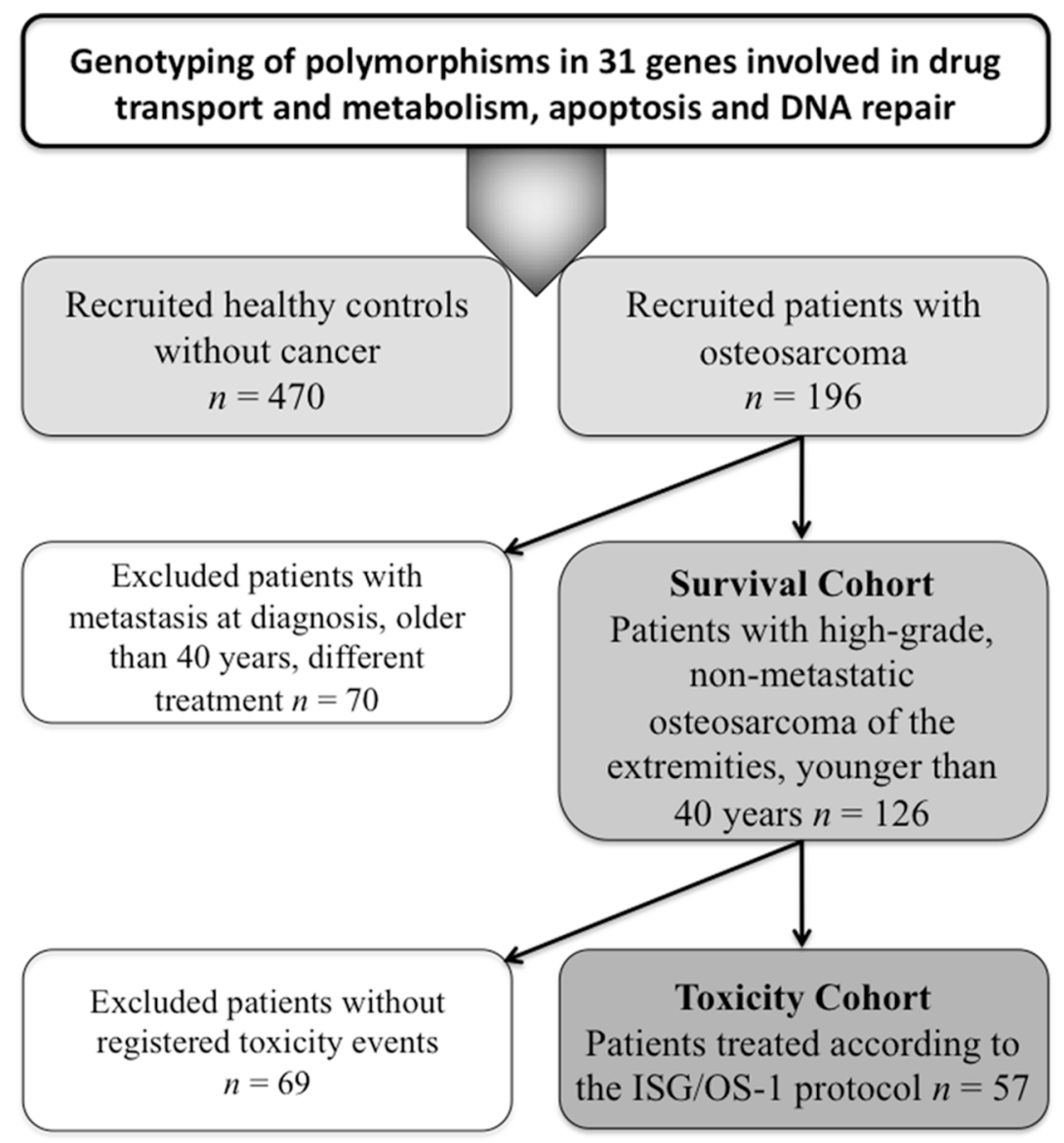

Figure 4: Flow diagram showing all cohorts included in genotyping and association analyses. 
Table 8: Polymorphisms and methods of analysis

\begin{tabular}{|c|c|c|c|c|}
\hline Main Gene Function & Gene Name_Polymorphism & Reference SNP Number & Method of Analysis & Reference \\
\hline \multirow{9}{*}{ 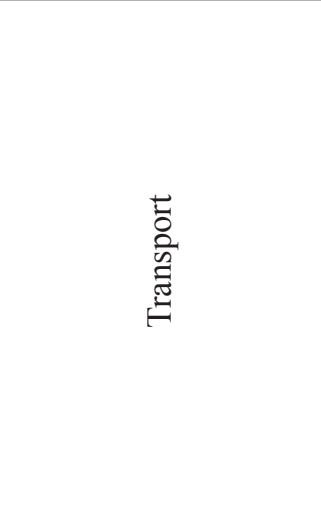 } & ABCB1_3435T/C & rs 1045642 & PSQ & [28] \\
\hline & ABCB1_1236T/C & rs1128503 & PSQ & [28] \\
\hline & ABCB1_2677G $>$ T/A & rs2032582 & PSQ & \\
\hline & ABCC2_1249A/G & rs2273697 & PSQ & [28] \\
\hline & $\mathrm{ABCC} 2-24 \mathrm{~A} / \mathrm{G}$ & rs 717620 & PSQ & [28] \\
\hline & ABCC2_3972A/G & rs 3740066 & taqman assay & \\
\hline & ABCG2_34A/G & rs2231137 & taqman assay & \\
\hline & ABCG2_421A/C & rs2231142 & taqman assay & \\
\hline & RFC_80A/G & rs 1051266 & PSQ & \\
\hline \multirow{11}{*}{ 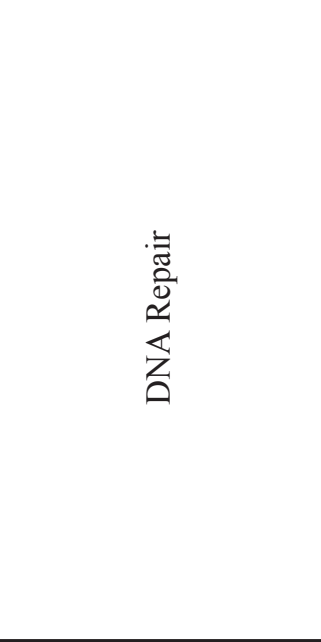 } & APE1_2197T/G & rs1130409 & taqman assay & \\
\hline & ERCC1_8092T/G & rs3212986 & taqman assay & [29] \\
\hline & ERCC1_19007T/C & rs11615 & taqman assay & [29] \\
\hline & hMLH1_676A/G & rs1799977 & PSQ & [28] \\
\hline & hMSH2_IVS12-6T/C & rs 2303428 & PSQ & [28] \\
\hline & hOGG1_1245C/G & rs 1052133 & taqman assay & [28] \\
\hline & XPD_35931T/G & rs13181 & PSQ & [29] \\
\hline & XPD_23591A/G & rs 1799793 & PSQ & [29] \\
\hline & XPG_3508G/C & rs 17655 & PSQ & [29] \\
\hline & XRCC1_28152A/G & rs25487 & taqman assay & [28] \\
\hline & XRCC3_18067T/C & rs 861539 & PSQ & [28] \\
\hline \multirow{11}{*}{ 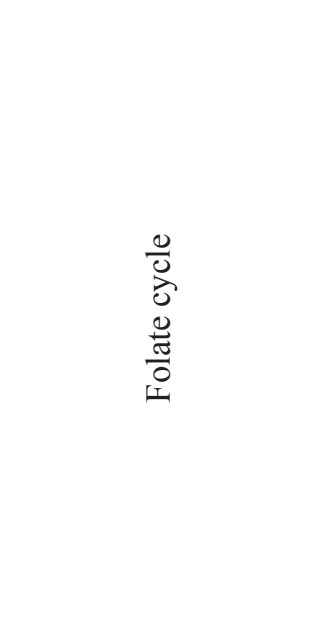 } & DHFR_Ins/Del & rs70991108 & PCR & \\
\hline & FOLR1_181delC & rs3833748 & RFLP/PSQ & \\
\hline & GGH_452T/C & rs 11545078 & taqman assay & \\
\hline & GGH_401T/C & rs3758149 & taqman assay & \\
\hline & GGH_16T/C & rs1800909 & taqman assay & \\
\hline & MTHFD1_1958T/C & rs 2236225 & taqman assay & \\
\hline & MTHFR_677T/C & rs 1801133 & PSQ & \\
\hline & MTHFR_1298A/C & rs1801131 & PSQ & \\
\hline & SHMT_1420T/C & rs 2273029 & taqman assay & \\
\hline & TYMS_28bp_VNTR & rs34743033 & PCR/RFLP & [30] \\
\hline & TYMS_1494del6 & rs 16430 & PCR/RFLP & {$[30]$} \\
\hline \multirow{7}{*}{ 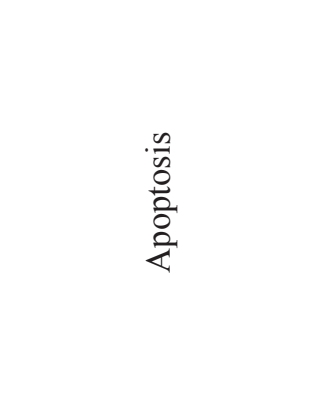 } & ATM_40C/G & rs 1800054 & taqman assay & \\
\hline & ATM_61A/G & rs 1801516 & taqman assay & \\
\hline & MDM2_309T/G & rs2279744 & PSQ & [14] \\
\hline & p21_98A/C & rs 1801270 & taqman assay & \\
\hline & TP53_PIN3_IVS3 + 16 bp & rs 17878362 & PCR & \\
\hline & TP53_IVS2+38G/C & rs 1642785 & taqman assay & \\
\hline & TP53_ex4+119G/C & rs1042522 & PSQ/taqman assay & [14] \\
\hline
\end{tabular}




\begin{tabular}{|c|c|c|c|c|}
\hline \multirow{9}{*}{ 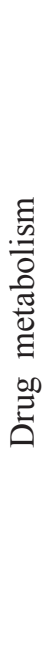 } & GSTT1_gen_null & rs_GSTT1_gen_null & PCR & {$[28]$} \\
\hline & GSTM1_gen_null & rs_GSTM1_gen_null & PCR & {$[28]$} \\
\hline & GSTP1_313A/G & rs 1695 & PSQ & \\
\hline & CYP2C19*2_681A/G & rs4244285 & PSQ & \\
\hline & $\begin{array}{l}\text { CYP2B6*6 } \\
(516 \mathrm{~T} / \mathrm{G}+785 \mathrm{~A} / \mathrm{G})\end{array}$ & $\begin{array}{l}\text { rs3745274 and } \\
\text { rs2279343 }\end{array}$ & RFLP & \\
\hline & $\begin{array}{l}\text { CYP2B6*7 } \\
\left({ }^{*} 6+1459 \mathrm{~T} / \mathrm{C}\right)\end{array}$ & $\begin{array}{l}\text { rs3745274 and } \\
\text { rs2279343 and } \\
\text { rs3211371 }\end{array}$ & RFLP & \\
\hline & CYP2C9*2_430T/C & rs1799853 & PSQ & \\
\hline & CYP2C9*3_1075A/C & rs 1057910 & PSQ & \\
\hline & CYP3A4*1B_-392A/G & rs2740574 & PSQ & \\
\hline
\end{tabular}

PSQ: pyrosequencing, PCR: polymerase chain reaction, RFLP: restriction fragment length polymorphism.

Logistic regression analysis was performed to estimate the odds ratios (OR) and the corresponding $95 \%$ confidence interval (CI) of each possible risk factor for the occurrence of adverse events.

Event-free survival (EFS) was calculated from diagnosis until the date of the first adverse event (relapse of the tumor at any site or death of disease) or the last follow-up examination. Survival curves for each polymorphism were drawn by the Kaplan-Meier method and statistical significance was determined by the log-rank test. The genotype status of the polymorphisms that were significantly associated with adverse survival was defined as "risk genotype".

Toxicity assessment was performed for each chemotherapy cycle and included incidence evaluation of grade 4 leukopenia and thrombocytopenia, red blood cell and platelet transfusion (as a consequence of the hematological toxicity), fever, nausea and vomiting, stomatitis, grade 4 transaminases (hepatotoxicity), nephroand neurotoxicity.

Polymorphisms significantly associated with adverse events in univariate analyses were also analyzed by Cox proportional hazards or multiple logistic regression analyses. Since this was an exploratory study, no multiple testing correction was applied, considering $p$ values and CIs more informative for the interpretation of our data.

All statistical analyses were carried out by using the StatView 5.0.1 software. Power calculations with real input data obtained from the survival and toxicity cohorts and a type I error probability of 0.05 were performed using the freely available Power and Sample size program [33].

\section{ACKNOWLEDGMENTS}

Authors would like to thank Dr. Giovanna Magagnoli for the biobanking managment of osteosarcoma patient samples. Andrea Roli thanks Roberto Serra, Marco
Villani and Alessandro Filisetti, who are co-authors of the works on the dynamical cluster index method.

\section{CONFLICTS OF INTEREST}

The authors have declared no conflicts of interest.

\section{GRANT SUPPORT}

This study was supported by grants from Associazione Italiana per la Ricerca sul Cancro (A.I.R.C.) [IG2014 I.d. 15851] and Istituto Ortopedico Rizzoli [5\% contributions to Rizzoli Institute].

\section{REFERENCES}

1. Anninga JK, Gelderblom $\mathrm{H}$, Fiocco $\mathrm{M}$, Kroep JR, Taminiau AH, Hogendoorn PC, Egeler RM. Chemotherapeutic adjuvant treatment for osteosarcoma: where do we stand? Eur J Cancer. 2011; 47:2431-2445.

2. Ferrari S, Serra M. An update on chemotherapy for osteosarcoma. Expert Opin Pharmacother. 2015; 16:2727-2736.

3. Hattinger CM, Fanelli M, Tavanti E, Vella S, Ferrari S, Picci P, Serra M. Advances in emerging drugs for osteosarcoma. Expert Opin Emerg Drugs. 2015; 20:495-514.

4. Yu W, Clyne M, Khoury MJ, Gwinn M. Phenopedia and Genopedia: disease-centered and gene-centered views of the evolving knowledge of human genetic associations. Bioinformatics. 2010; 26:145-146.

5. Savage SA, Mirabello L, Wang Z, Gastier-Foster JM, Gorlick R, Khanna C, Flanagan AM, Tirabosco R, Andrulis IL, Wunder JS, Gokgoz N, Patino-Garcia A, Sierrasesumaga L, et al. Genome-wide association study identifies two susceptibility loci for osteosarcoma. Nat Genet. 2013; 45:799-803. 
6. Patino-Garcia A, Zalacain M, Marrodan L, San-Julian M, Sierrasesumaga L. Methotrexate in pediatric osteosarcoma: response and toxicity in relation to genetic polymorphisms and dihydrofolate reductase and reduced folate carrier 1 expression. J Pediatr. 2009; 154:688-693.

7. Cotton SC, Sharp L, Little J, Brockton N. Glutathione S-transferase polymorphisms and colorectal cancer: a HuGE review. Am J Epidemiol. 2000; 151:7-32.

8. Lang T, Klein K, Fischer J, Nussler AK, Neuhaus P, Hofmann U, Eichelbaum M, Schwab M, Zanger UM. Extensive genetic polymorphism in the human CYP2B6 gene with impact on expression and function in human liver. Pharmacogenetics. 2001; 11:399-415.

9. Serra M, Hattinger CM. The pharmacogenomics of osteosarcoma. Pharmacogenomics J. 2016:in press.

10. McTiernan A, Jinks RC, Sydes MR, Uscinska B, Hook JM, van Glabbeke M, Bramwell V, Lewis IJ, Taminiau AH, Nooij MA, Hogendoorn PC, Gelderblom H, Whelan JS. Presence of chemotherapy-induced toxicity predicts improved survival in patients with localised extremity osteosarcoma treated with doxorubicin and cisplatin: a report from the European Osteosarcoma Intergroup. Eur J Cancer. 2012; 48:703-712.

11. Caronia D, Patino-Garcia A, Perez-Martinez A, Pita G, Moreno LT, Zalacain-Diez M, Molina B, Colmenero I, Sierrasesumaga L, Benitez J, Gonzalez-Neira A. Effect of $\mathrm{ABCB} 1$ and $\mathrm{ABCC} 3$ polymorphisms on osteosarcoma survival after chemotherapy: a pharmacogenetic study. PLoS One. 2011; 6:e26091.

12. Windsor RE, Strauss SJ, Kallis C, Wood NE, Whelan JS. Germline genetic polymorphisms may influence chemotherapy response and disease outcome in osteosarcoma: a pilot study. Cancer. 2012; 118:1856-1867.

13. Cai X, Yang M. The functional MDM2 T309G genetic variant but not P53 Arg72Pro polymorphism is associated with risk of sarcomas: a meta-analysis. J Cancer Res Clin Oncol. 2012; 138:555-561.

14. Toffoli G, Biason P, Russo A, De Mattia E, Cecchin E, Hattinger CM, Pasello M, Alberghini M, Ferrari C, Scotlandi K, Picci P, Serra M. Effect of TP53 Arg72Pro and MDM2 SNP309 polymorphisms on the risk of high-grade osteosarcoma development and survival. Clin Cancer Res. 2009; 15:3550-3556.

15. Wang L, Liu Z, Jing P, Shao L, Chen L, He X, Gong W. Effects of murine double minute 2 polymorphisms on the risk and survival of osteosarcoma: a systemic review and meta-analysis. Tumour Biol. 2014; 35:1649-1652.

16. Mirabello L, Yeager M, Mai PL, Gastier-Foster JM, Gorlick R, Khanna C, Patino-Garcia A, Sierrasesumaga L, Lecanda F, Andrulis IL, Wunder JS, Gokgoz N, Barkauskas DA, et al. Germline TP53 variants and susceptibility to osteosarcoma. J Natl Cancer Inst. 2015; 107.

17. Savage SA, Burdett L, Troisi R, Douglass C, Hoover RN, Chanock SJ. Germ-line genetic variation of TP53 in osteosarcoma. Pediatr Blood Cancer. 2007; 49:28-33.
18. Hagleitner MM, Coenen MJ, Gelderblom H, Makkinje RR, Vos HI, de Bont ES, van der Graaf WT, Schreuder HW, Flucke U, van Leeuwen FN, Hoogerbrugge PM, Guchelaar HJ, Te Loo DM. A First Step toward Personalized Medicine in Osteosarcoma: Pharmacogenetics as Predictive Marker of Outcome after Chemotherapy-Based Treatment. Clin Cancer Res. 2015; 21:3436-3441.

19. Hattinger CM, Serra M. Role of pharmacogenetics of drugmetabolizing enzymes in treating osteosarcoma. Expert Opin Drug Metab Toxicol. 2015; 11:1449-1463.

20. Fanelli M, Hattinger CM, Vella S, Tavanti E, Michelacci F, Gudeman B, Barnett D, Picci P, Serra M. Targeting ABCB1 and $\mathrm{ABCC} 1$ with their Specific Inhibitor CBT-1((R)) can Overcome Drug Resistance in Osteosarcoma. Curr Cancer Drug Targets. 2016; 16:261-274.

21. Bruhn O, Cascorbi I. Polymorphisms of the drug transporters $\mathrm{ABCB} 1, \mathrm{ABCG} 2, \mathrm{ABCC} 2$ and $\mathrm{ABCC} 3$ and their impact on drug bioavailability and clinical relevance. Expert Opin Drug Metab Toxicol. 2014; 10:1337-1354.

22. Laechelt S, Turrini E, Ruehmkorf A, Siegmund W, Cascorbi I, Haenisch S. Impact of ABCC2 haplotypes on transcriptional and posttranscriptional gene regulation and function. Pharmacogenomics J. 2011; 11:25-34.

23. Mikkelsen TS, Thorn CF, Yang JJ, Ulrich CM, French D, Zaza G, Dunnenberger HM, Marsh S, McLeod HL, Giacomini K, Becker ML, Gaedigk R, Leeder JS, et al. PharmGKB summary: methotrexate pathway. Pharmacogenet Genomics. 2011; 21:679-686.

24. Cheng Q, Wu B, Kager L, Panetta JC, Zheng J, Pui CH, Relling MV, Evans WE. A substrate specific functional polymorphism of human gamma-glutamyl hydrolase alters catalytic activity and methotrexate polyglutamate accumulation in acute lymphoblastic leukaemia cells. Pharmacogenetics. 2004; 14:557-567.

25. Hofmann MH, Blievernicht JK, Klein K, Saussele T, Schaeffeler E, Schwab M, Zanger UM. Aberrant splicing caused by single nucleotide polymorphism c.516G $>\mathrm{T}$ [Q172H], a marker of CYP2B6*6, is responsible for decreased expression and activity of CYP2B6 in liver. J Pharmacol Exp Ther. 2008; 325:284-292.

26. Cascorbi I. Role of pharmacogenetics of ATP-binding cassette transporters in the pharmacokinetics of drugs. Pharmacol Ther. 2006; 112:457-473.

27. Ferrari S, Ruggieri P, Cefalo G, Tamburini A, Capanna R, Fagioli F, Comandone A, Bertulli R, Bisogno G, Palmerini E, Alberghini M, Parafioriti A, Linari A, et al. Neoadjuvant chemotherapy with methotrexate, cisplatin, and doxorubicin with or without ifosfamide in nonmetastatic osteosarcoma of the extremity: an Italian sarcoma group trial ISG/OS-1. J Clin Oncol. 2012; 30:2112-2118.

28. Cecchin E, Agostini M, Pucciarelli S, De Paoli A, Canzonieri V, Sigon R, De Mattia E, Friso ML, Biason P, Visentin M, Nitti D, Toffoli G. Tumor response is predicted by patient genetic profile in rectal cancer 
patients treated with neo-adjuvant chemo-radiotherapy. Pharmacogenomics J. 2011; 11:214-226.

29. Biason $\mathrm{P}$, Hattinger CM, Innocenti F, Talamini R, Alberghini M, Scotlandi K, Zanusso C, Serra M, Toffoli G. Nucleotide excision repair gene variants and association with survival in osteosarcoma patients treated with neoadjuvant chemotherapy. Pharmacogenomics J. 2012; 12:476-483.

30. Biason P, Visentin M, Talamini R, Stopar A, Giorda G, Lucia E, Campagnutta E, Toffoli G. Polymorphic thymidylate synthase gene impacts on overall survival of patients with epithelial ovarian cancer after platinum-based chemotherapy. Pharmacogenomics. 2012; 13:1609-1619.
31. Tononi G, McIntosh AR, Russell DP, Edelman GM. Functional clustering: identifying strongly interactive brain regions in neuroimaging data. Neuroimage. 1998; 7:133-149.

32. Villani M, Roli A, Filisetti A, Fiorucci M, Poli I, Serra R. The Search for Candidate Relevant Subsets of Variables in Complex Systems. Artif Life. 2015; 21:412-431.

33. Dupont WD, Plummer WD Jr. Power and sample size calculations for studies involving linear regression. Control Clin Trials. 1998; 19:589-601. 